NBER WORKING PAPER SERIES

\title{
ECONOMIC STATUS AND HEALTH IN CHILDHOOD: THE ORIGINS OF THE GRADIENT
}

\author{
Anne Case \\ Darren Lubotsky \\ Christina Paxson \\ Working Paper 8344 \\ http://www.nber.org/papers/w8344 \\ NATIONAL BUREAU OF ECONOMIC RESEARCH \\ 1050 Massachusetts Avenue \\ Cambridge, MA 02138 \\ June 2001
}

We thank David Card, Janet Currie, Angus Deaton and seminar participants at Princeton and the NBER for helpful suggestions, and the John D. and Catherine T. MacArthur Foundation for financial support. The views expressed herein are those of the authors and not necessarily those of the National Bureau of Economic Research.

(C) 2001 by Anne Case, Darren Lubotsky and Christina Paxson. All rights reserved. Short sections of text, not to exceed two paragraphs, may be quoted without explicit permission provided that full credit, including (C) notice, is given to the source. 
Economic Status and Health in Childhood: The Origins of the Gradient Anne Case, Darren Lubotsky and Christina Paxson

NBER Working Paper No. 8344

June 2001

JEL No. I1

\begin{abstract}
$\underline{\text { ABSTRACT }}$
We show that the well-known positive association between health and income in adulthood has antecedents in childhood. Using the National Health Interview Surveys, the Panel Study of Income Dynamics, and the National Health and Nutrition Examination Survey, we find that children's health is positively related to household income. The relationship between household income and children's health status becomes more pronounced as children grow older. A large component of the relationship between income and children's health can be explained by the arrival and impact of chronic health conditions in childhood. Children from lower-income households with chronic health conditions have worse health than do children from higher-income households. Further, we find that children's health is closely associated with long-run average household income, and that the adverse health effects of lower permanent income accumulate over children's lives. Part of the intergenerational transmission of socioeconomic status may work through the impact of parents' long run average income on children's health.
\end{abstract}

Anne Case*

345 Wallace Hall

Princeton University

Princeton NJ 08544-1013

(609) 258-2177

accase@princeton.edu

*Corresponding author
Darren Lubotsky

339 Wallace Hall

Princeton University

Princeton NJ 08544-1013

(609) 258-6917

lubotsky@princeton.edu
Christina Paxson

316 Wallace Hall

Princeton University

Princeton NJ 08544-1013

(609) 258-6474

cpaxson@princeton.edu 


\section{Introduction}

That wealthy people live longer and have lower morbidity, on average, than do poor people has been well documented across countries, within countries at a point in time, and over time with economic growth. The positive correlation between income and health is not limited to the bottom end of the income distribution (Adler et al 1994). Indeed, the gradient in health status-the phenomenon that relatively wealthier people have better health and longevity—is evident throughout the income distribution. In this paper we present evidence that the income gradients observed in adult health have antecedents in childhood, and suggest that part of the intergenerational transmission of socioeconomic status may work through the impact of parents' long run average income on children's health.

Using several large, nationally representative data sets, we find that children's health is positively related to household income, and that the relationship between household income and children's health status becomes more pronounced as children grow older. A large component of the relationship between income and children's health can be explained by the arrival and impact of chronic health conditions in childhood. Children from lower-income households with chronic health conditions have worse health than do children from higher-income households. Further, we find that children's health is closely associated with long-run average household income, and that the adverse health effects of lower permanent income accumulate over children's lives. These children arrive at the doorstep of adulthood with lower health status and lower educational attainment — the latter, in part, as a consequence of poor health.

Our findings are of interest not only because they provide insight into the determinants of child well-being, but because they have implications for the sources of an income gradient in adulthood health. Hypotheses on the causes of the relationship between income and health are difficult to untangle in adulthood, and there is little consensus on the relative importance of mechanisms that lead from low income to poor health and of those that lead from poor health to low income. (Marmot 1999, Smith 1999, Fuchs 1982). By focusing on children, we can eliminate 
the channel that runs from health to income. Generally in the United States children do not contribute to family income, and so the correlation between poor health in childhood and low family income cannot be explained by lower earnings of children (although it should be noted that ill children could reduce parental labor supply, a point we address in what follows). This does not imply that health status has no effect on income in adulthood. In fact, our results indicate that children from poorer households enter adulthood in poorer general health, with more serious chronic conditions, and having missed more days of school—all of which may compromise their future earnings ability.

Wealthier parents may be better able to purchase medical care, nutritious foods, and safer environments for their children and, in these and many other ways, income may have a causal effect on children's health. At the same time, children's health may be influenced by a variety of

parental characteristics — including both genetic or behavioral factors - that are correlated with parental income, and we find evidence for some 'third factor' explanations in our data.

We begin by establishing several facts about the relationship between children's health and household income. We then present a model of the evolution of children's health status that is consistent with the facts presented, and go on to test implications of the model. We then explore the extent to which the relationship between income and health can be explained by other characteristics of parents and the child's environment, such as parental health and labor supply. We conclude with a discussion of mechanisms that underlie the relationship between income and health in childhood, and implications of this relationship for children's human capital formation.

\section{Data}

In our analysis we use data from four sources: the annual National Health Interview Survey (NHIS), the 1988 child health supplement to the NHIS (NHIS-CH), the Panel Study of Income Dynamics with its associated 1997 Child Development Supplement (PSID-CDS), and the Third National Health and Nutrition Examination Survey (NHANES). 
The NHIS is a cross-sectional survey that collects annual data on the health status and chronic and acute medical conditions of a large nationally representative sample of American adults and children. We pool NHIS data from 1986 to 1995, which yields roughly 62,000 observations for 1986, and 120,000 observations annually between 1987 and 1995. Our interest is in understanding the relationship between family income and children's health, and for this reason we restrict our 'core' sample to all children aged 0 to 17 for whom household income is reported. The NHIS contains information on total household income, presented by income band. We assign incomes to these income categories using data from the 1986-1995 March Current Population Surveys. (Detailed information on the sample and on the income assignment procedure is provided in the Appendix.)

Summary statistics for our core NHIS sample of children are provided in column 1 of Table 1 . The children are on average 8.3 years old (we have roughly equal numbers at each age), and are on average in very good or excellent health. Only 3 percent of them are reported to be in only fair or poor health. Less than 2 percent of the children are living apart from a mother; 20 percent are living apart from a father. The sample is roughly 78 percent white and 15 percent black.

The sample for the 1988 NHIS-CH consists of one child per family drawn from the 1988 NHIS. The respondents for these children were asked a wide variety of questions regarding the child's health. We use the NHIS-CH to examine issues related to the child's health at birth and the child's health insurance coverage, for which there is no information in the core NHIS.

Most of our PSID data come from a Child Development Supplement that was conducted in 1997, in which a battery of health-related questions was asked of (a maximum of) two children aged 12 or under in all PSID households. Information was gathered on the children's current health status and their health status at birth. We supplement the 1997 data with information on family income and their parents' work histories and health status from earlier years of the PSID. 
Summary statistics for the PSID sample are given in the second column of Table 1 . The PSID children are on average younger than the NHIS children (they range in age from 0 to 12 , instead of from 0 to 17). Their health is also generally very good or excellent. The PSID sample is less white (52 percent) and more black (42 percent) than the NHIS. Part of our sample comes from the PSID-SEO, which intentionally oversampled the poor.

The Third National Health and Nutrition Examination Survey (NHANES) was conducted between 1988 and 1994. As part of the survey, respondents were given an examination by a physician, who was then asked to rate the individual's general health status on a scale of 1 (excellent) to 5 (poor). We use data on 10,018 children aged 16 and under to compare the relationship between family income and the doctor's assessment of overall health with that observed between family income and the child's parent's assessment measured on the same scale. More details are provided in the Appendix. Sample statistics for the NHANES are shown in the third column of Table 1. These (unweighted) means reflect the fact that the NHANES oversampled young children from lower-income demographic groups: these children are younger and poorer, with lower levels of adult education.

\section{The income-gradient in children's health status}

We first look at the relationship between family income and overall health status, where health status is a categorical variable with values $1=$ Excellent, 2=Very Good, 3=Good, 4=Fair, and 5=Poor. Finding appropriate measures of a child's health status is a challenge. In developing countries, infant mortality rates, anthropometric measures, and indicators for vaccination provide a guide to child health. Using U.S. data, Korenman and Miller (1997) examine how the timing of

poverty is related to stunting, wasting, obesity, and several indicators of child development among a sample of 5 to 7 year olds from the NLSY. However, in the U.S., stunting and wasting are quite rare. For adults, a poor self-report of health is a powerful predictor of mortality, even when controlling for physician assessed health status and health-related behaviors. Poor self-reports of 
health are also a significant predictor of future changes in functioning among the elderly. (Idler and Kasl 1995 presents results on changes in functioning, and an extensive set of references on the studies of self reported health and mortality.) Much less is known about the predictive power of reported poor health in children. In what follows, we find that this measure correlates strongly with children's chronic conditions, bed days, and hospitalization episodes.

The upper half of Figure 3.1 shows the conditional expectation of health status in the NHIS as a function of the log of family income, for children by age group in the left-hand panel, and for younger and older adults by age group in the right-hand panel. The bottom half shows similar graphs for the PSID, although the samples of adults for the PSID consist of parents of the children in the PSID-CDS and so are not representative of all adults in the United States. The conditional expectations are calculated using a Fan (1992) locally weighted regression smoother, which allows the data to determine the shape of the function, rather than imposing (for example) a linear or quadratic form. The top left panel of Figure 3.1 presents results for children ages 0-3, 4$8,9-12$, and 13-17, and the right panel presents those same children 13-17, and compares them with adults of different ages. ${ }^{1}$ The PSID uses the same age groupings for children (up to age 12), and two groupings of parents, aged 25-34 and 35-44.

Immediately apparent in the left panel of Figure 3.1 is the inverse relationship between family income and children's health status for children of all ages. The correlation becomes progressively more negative with age — a phenomenon that holds throughout childhood and adulthood (note the change in scale between the panels). This steepening of the gradient with age is observed until roughly age 65 , a result consistent with the findings of other researchers. The results for the PSID are similar to those for the NHIS.

${ }^{1}$ The Fan regressions are weighted using sampling weights provided in the NHIS, and are thus representative of the population as a whole. (Unweighted regression results are very similar.) We do not include adults aged 18-24 in this second panel, because we are concerned about the representativeness of this sample of college-aged individuals, and whether these respondents report their current incomes or the incomes of the families in which they were raised. 
Our findings contrast with those found by West (1997). Using the 1991 British Census, West concludes that the gradient found among children disappears for youths (ages 11-19), only to reappear in early adulthood (ages 20 and higher). We find that the gradient in reported health status found in childhood becomes more pronounced as youths age, and no evidence that the gradient vanishes in adolescence.

There are many other parental, household and child-specific characteristics that may vary between households with 2 year olds (say) and households with 12 year olds. In order to control for a range of other characteristics, we run ordered probits of health status (integers from $1=$ excellent to $5=$ poor) on income and on sets of household controls, and present the results in the first four columns of Table 2 for the NHIS. ${ }^{2}$

We present two sets of results for each age group. The first row (labeled "NHIS Controls 1") shows results of ordered probits of health status on the log of family income, with age indicators, year indicators, and with controls for child and household characteristics, excluding parents' educations. (Details are given in the notes to the tables.) The next set of rows ("NHIS Controls 2") presents results in which, in addition to the variables in Controls 1, we include controls for parents' educations and unemployment status. The results in Table 2 show that the negative relationship between income and health status becomes more pronounced and significant for each older age group.

The addition of parents' educational attainment to the set of controls has a large effect on the estimated income coefficients, reducing them by roughly a third for all ages relative to results using Controls 1 . However, the gradients remain large and highly significant. Even with controls for parents' educations, a doubling of household income is associated with an increase in the probability that a child is in excellent or very good health of 4.0 percent (for ages $0-3$ ), 4.9

${ }^{2}$ The results presented here are robust to estimating the models using ordinary least squares, and to using an indicator that health is reported to be 'excellent' or 'very good' as the dependent variable. 
percent (ages 4-8), 5.9 percent (ages 9-12) and 7.2 percent (ages 13-17). (These results are not reported in Table 2, but are available from the authors upon request.)

Although adding controls for education does not eliminate the effects of income, the coefficients on parents' educations are large and significant. Children living with a mother with a high school degree are reported to be in better health than those whose mothers have not finished high school (the omitted category here). Children whose mothers have more than a high school degree are reported to be in even better health. A similar pattern is seen with respect to fathers' educations. This may be because education makes parents more adept at protecting their children's health. Alternatively, education itself may not be causal, but may signify that the parent is patient, and may be more nurturing. In either case, if parents' educations are omitted, their effects may load onto the income coefficient, with which they are highly correlated. ${ }^{3}$

Distinct from the pattern we observed for income, we see little change in the impact of parents' educations on children's health status between younger and older ages. Both mothers' and fathers' educations have a slightly stronger impact for children above age 3 ; the coefficient on the indicator that mother has more than a high school degree, for example, jumps from -.244 to -.322 between age groups 0 to 3 and 4 to 8 . However, a comparison of the education coefficients for children aged 4 to 8,9 to 12 and 13 to 17 show that the relationship between parents educations and childrens' health remain constant above age 3 . That there is a steepening gradient

\footnotetext{
${ }^{3}$ Another explanation is that household income is measured with error, and the 'true' household income may be correlated with parents' educations, leading to large (or larger) coefficients on parents' educations, as the education coefficients pick up part of the effect of 'true' income. We have explored whether measurement error in income is important in our analysis, by instrumenting the log of family income on indicators for industry, occupation and class of worker in the household. For each age group and each specification, the instrumented coefficients show a stronger effect of income on health status, increasing the size of the coefficients in absolute value between twenty five and fifty percent. Other than its effect on the sizes of the coefficients, instrumentation does little to the pattern of coefficients observed here: the gradients for older children continue to be steeper than those for younger children. Instrumentation does reduce the estimated effects of mother's and father's educations, but their coefficients remain large and significant.
} 
of health with respect to income with age, but no steepening with respect to parents' educations, is noteworthy. It appears that income (and what it buys a child) has a different effect on a child's health from the skills that accompany parental education.

One potential objection to the use of parents' reports of their children's health status is that they are not objective, and may be colored by the parent's own health status. Such a finding would be inconsistent with Dadds et al (1995), who present evidence that maternal mental health does not influence mothers' reports of child health. We provide three additional pieces of evidence on this issue. First, we look at 17-year-olds in the NHIS, who were given the option of reporting on their own health. Specifically, we reproduced the results shown in the top panel of Table 2, adding both an indicator for whether the 17-year-olds responded for themselves and an interaction term of the logarithm of income with this indicator. In no case was the effect of either of the added variables significantly different from zero.

In addition, because the NHANES contains both physician-assessed and parent-assessed health status, we can evaluate whether the gradient we observe using parent-assessed health, and the rotation of this gradient with age, are due to a reporting bias that varies systematically with income. The bottom panel of Table 2 presents coefficients of log family income in ordered probits of parent-assessed health (columns 1 to 4), and physician-assessed health (columns 5 to 8). For both, we find a significant correlation between income and children's health status, with larger effects for older children. The coefficients on income for physician-assessed health are smaller in absolute value than those for parent-assessed health, possibly because physicians use a smaller range of the health scale than do parents. That the income gradient in physician-assessed health status also rotates with children's ages (at least through age 12) suggests that the rotation we see in parent-assessed health is not the result of reporting bias.

A third way of evaluating the gradients we find using parent reports of children's health is to compare them with those we find for other health related outcomes. The last four NHIS columns of Table 2 report the gradients we observe for the number of days the child has spent in 
bed and the number of hospitalization episodes in the past 12 months, and the number of school days missed and days of restricted activity in the past 2 weeks. For all four of these measures of children's health status we find large and significant effects of family income. These, then, provide additional evidence that either income is itself protective of children's health, or is correlated with things that are protective of children's health. Perhaps both.

We finish our initial presentation of the facts by examining whether there are gradients in the medical conditions that children contract. We selected a set of 14 potentially serious health conditions on which the NHIS collects information, leaving aside conditions that are not associated with children (e.g. emphysema, arthritis, cirrhosis of the liver.) Most of the conditions we consider are "chronic" in the sense that the fraction of children who have these conditions increases with age. Exceptions are digestive disorders, which are most common among very young children, and bronchitis. Detailed information on these conditions is provided in the Appendix. Figure 3.2 parallels Figure 3.1, and shows non-parametric regressions of an indicator of having a medical condition on the log of family income for children in different age groups. We have graphed 9 of the 14 conditions to illustrate the diversity of relationships between specific medical conditions and income. The vertical lines in the figures are placed at the $25^{\text {th }}, 50^{\text {th }}$ and $75^{\text {th }}$ percentiles of income.

Many of the conditions are more prevalent at lower incomes for all age groups. These include digestive disorders, hearing problems, heart conditions, epilepsy, and mental retardation. Others display a negative relationship between prevalence and income for some but not all ages. For example, there is a negative association between asthma and income for children aged 8 and under, but not for older children. This result is consistent with Halfon and Newacheck (1993), who find that the difference in the prevalence of asthma across children above and below the poverty line is largest for young children. However, our results indicate that the negative association between asthma and income for younger children is not driven solely by a higher 
prevalence of asthma among children in poverty: the negatively sloped gradient is apparent up through the $50^{\text {th }}$ percentile of income, well above the poverty line.

The next section presents a model of children's health status that is consistent with the preliminary findings of this section: that, on average, children's health becomes poorer with age; that, on average, the differences in the health of wealthier and poorer children become more pronounced with age; and that, on average, the probability of developing a severe chronic condition is inversely related to income.

\section{A model of cumulative health status}

In this section we build a model in which incomes have cumulative effects on health. Health stocks depends on both the accumulation of medical conditions and the effort and money parents spend to prevent the deterioration in their children's health when they become ill. The model has implications that are consistent with our previous results — both that older children on average are reported to have poorer health, and that the gradient in health steepens with age-and also has a variety of other testable implications that we examine below.

We assume, to begin, that all children are born into excellent health status, $h^{*}$, and that children's health erodes only as they receive health shocks, which arrive in the form of chronic conditions. If a child never contracts a chronic condition, then the child's health will remain at the highest level. (Below we relax the assumption that all children have identical, excellent health status at birth. We can also allow for non-chronic health shocks that do not persist over time, such as common colds or stomach viruses, that might temporarily reduce reported health status.)

Chronic conditions accumulate over time. We define $c_{t}$ to be an index of the number and severity of chronic conditions a child has. Each period, $c$ can increase, either because the child receives a new chronic condition or an existing chronic condition worsens. A simple (discrete) process for the accumulation of chronic conditions is:

$$
c_{t}=c_{t-1}+d_{t} \text {. }
$$


where $d_{t}$ is an integer that ranges from 0 to $\mathrm{D}$, such that each value has a probability of occurring of $p_{d}$, where $\sum_{d=0}^{D} p_{d}=1$. In this specification, chronic conditions can increase but not decrease over time. It is sensible but not necessary to assume that $p_{d}$ decreases in $d$. Consistent with the evidence presented in Figure 3.2, we assume that the probabilities $p_{d}$ are a decreasing function of income.

A child's stock of health $h$ evolves through time. Chronic conditions $c$ erode the child's health stock by an amount $\delta(c) h$, where the fraction of health stock lost to illness each period $\delta(c)$ depends upon the number and severity of conditions. Without proper treatment, a child with asthma, for example, is at greater risk of developing respiratory viral infections, which may in turn lead to lower health status. We assume children with no chronic conditions experience no erosion in their health stock: $\delta(c=0)=0$.

To a greater or lesser extent, depreciation in the child's health stock may be offset by household (parental) investments in the child's health. Here we assume that investments can be characterized as investments per unit of the child's current health $e(y, h) h$, where the investment is a function of the child's current health status and the family's income $y$. For the moment we leave open the question of what income measure is most relevant to a child's health investments current income or long-run average income are both plausible candidates. Such investments may take many forms. For example, the parents of a child with asthma may invest time and effort in helping to develop and monitor a medical protocol that works for their child; they may keep the child's medications up to date, and his or her inhaler in working order. Parents may also change their own behaviors, perhaps refraining from smoking near the child, or ensuring that dust mites aren't aggravating the child's condition. As written here, the investment function includes both medical services purchased and health-related behaviors (nutrition, smoking, exercise).

The two critical assumptions we make about the investment function are that, at any given level of health stock, wealthier parents are willing (able) to invest more, so that $\partial e(y, h) / \partial y>0$, and that all parents are willing to invest more when a child's health becomes poorer, so that 
$\partial e(y, h) / \partial h<0$. We also assume that as long as children are observed in excellent health, no investment is made in their health: $e\left(y, h^{*}\right)=0$. Figure 4.1 displays a configuration of the relationship between a child's health and the health investment for the wealthiest household in the survey, $\bar{y}$, and the poorest household in the survey, $\underline{y}$. We have drawn health investments to be linear in the child's health stock, but the exact shape of the investment profile is not essential.

Figure 4.1 Children's health status, conditions and family income

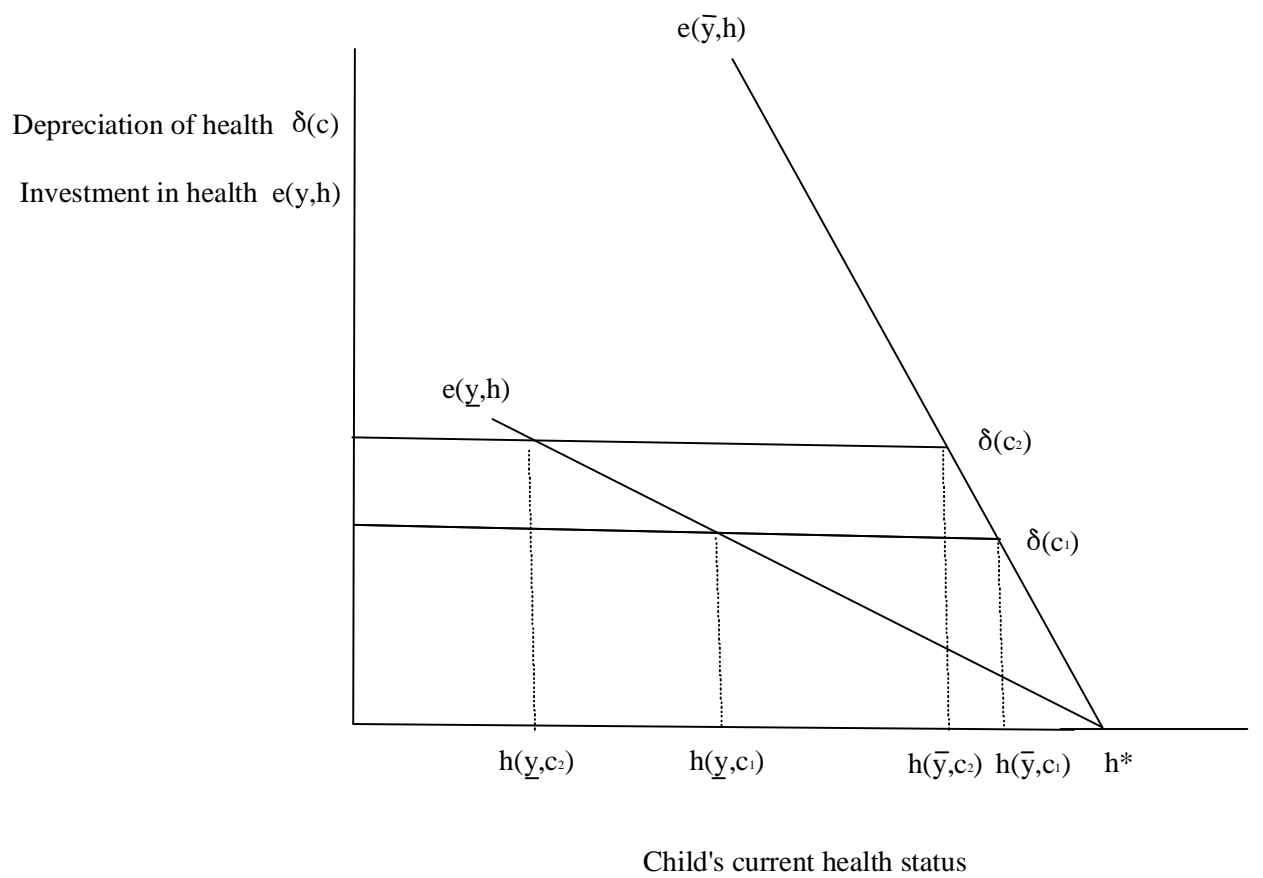

In this model, a child's health stock evolves as a function of the child's chronic conditions, his or her current health stock, depreciation of the current stock, and investments made by parents:

$$
h_{t}=h_{t-1}-\delta\left(c_{t-1}\right) h_{t-1}+e\left(y, h_{t-1}\right) h_{t-1} .
$$


Conditional on the child's conditions, health transitions toward a steady state are determined by parents' investments and the severity of the conditions faced. Assuming the arrival of no additional conditions, steady state would be reached when:

$$
e(y, h)=\delta(c) .
$$

There will be no steady state for a child facing a set of conditions serious enough, $\tilde{c}$, and an income level low enough, $\tilde{y}$, that $e\left(\tilde{y}, h_{\min }\right)<\delta(\tilde{c})$, where $h_{\min }$ is a level of health so low that, below this level, children die: facing these conditions with the investment parents can afford to make, a child's health will continue to erode until he or she dies.

Figure 4.1 shows the steady state values for children with the same number of conditions from the wealthiest and poorest households. Holding income constant, children with more chronic conditions are less healthy. Holding the number of conditions constant, children with less income are less healthy. The model predicts that, for any non-zero level of chronic conditions, say $c_{1}$, the steady state health level for poor children will be below that for rich children, $h\left(\underline{y}, c_{1}\right)<h\left(\bar{y}, c_{1}\right)$, as in Figure 4.1.

We illustrate the health dynamics implied by this model with the following example. Suppose a rich child and a poor child of the same age both developed a chronic condition, $c_{1}$, at time $t$. The model predicts that at $t+1$ the health of both children will have deteriorated somewhat, because the families do not spend resources on the children's health when the children are in excellent health, and it takes time for the condition to erode health status. But once the erosion is observed, the wealthy family is able to bring more resources to bear to shore up the health of their child. The wealthy family may be able to stem the deterioration in the child's health status at time $t+1$, while the poor family may observe additional deterioration until $t+2$ (or perhaps beyond), until the child reaches a health level $h$ such that $e(\underline{y}, h)=\delta(c)$. The rich and poor child, when observed in cross section, would be presented with identical health status at time $t$ and $t+1$. It is only at time $t+2$ and beyond that the gradient in these children's health appears. 
This is shown in Figure 4.2, where the health status of a rich child and a poor child are graphed against age. The status of both children are shown after a health shock at age 0

(time $t$ ). The gradient in these children's health status appears only after age 1 (time $t+1$ ), when the differences in the treatment they receive for their chronic conditions begins to be reflected in their health. If at age 3 these children were both to develop a second chronic condition, erosion of their health from their current levels brings more resources to bear, and again the wealthy family stems the erosion with less loss of health than does the poor family. If the slope of the expenditure function with respect to health is steeper for the wealthy family than for the poor family at these

Figure 4.2 The evolution of children's health status

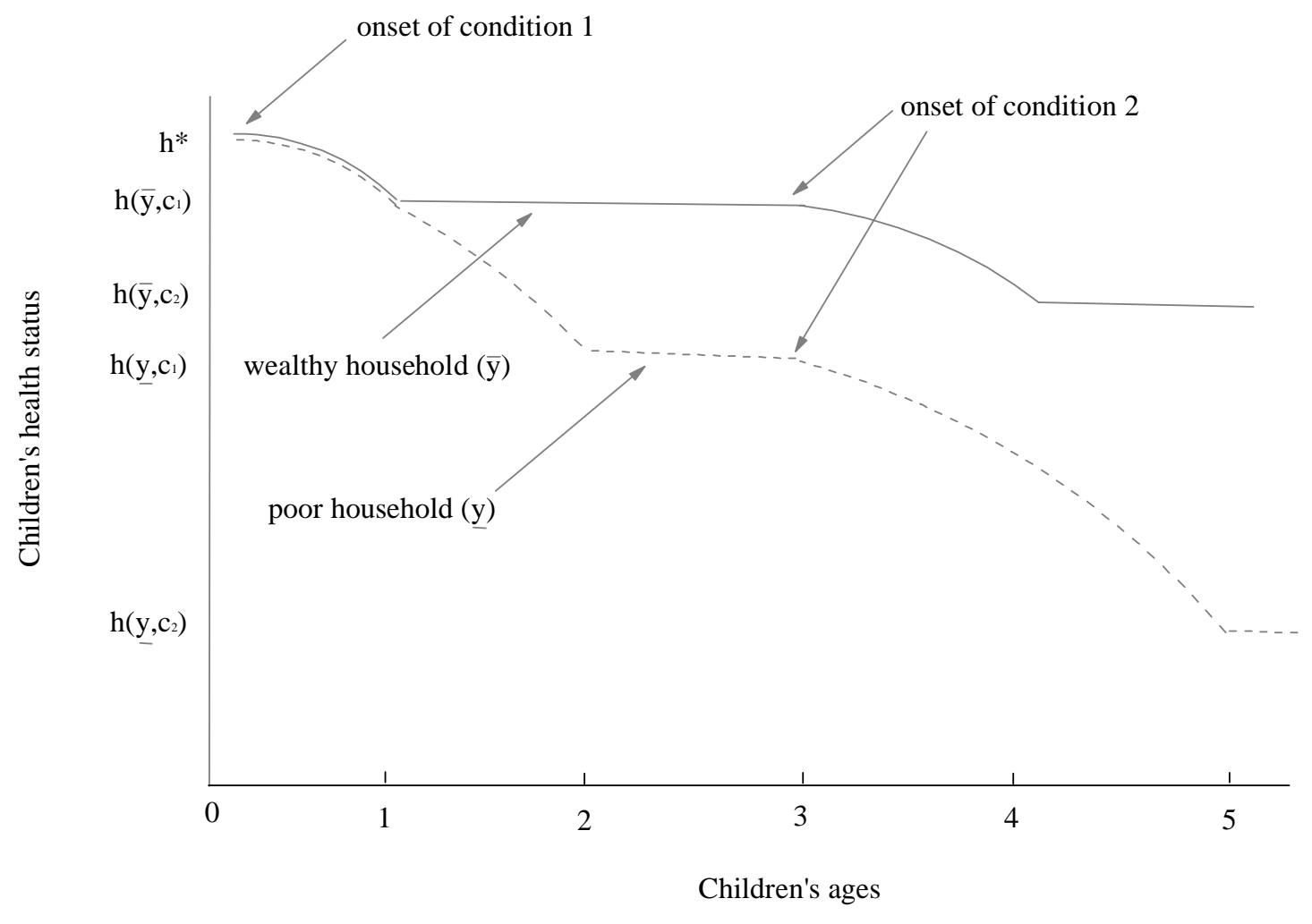

levels of health, then the difference in the children's health will widen after the onset of this new condition. This is shown both in Figure 4.1 and 4.2 as the difference between $h\left(\underline{y}, c_{2}\right)$ and $h\left(\bar{y}, c_{2}\right)$. 
The model has a variety of implications for the relationship between health, chronic conditions, and income:

(i) Children who suffer from no conditions remain in excellent health but, given the stochastic arrival of chronic conditions, on average the health of children will deteriorate with age. As conditions accumulate over time, erosion becomes a larger problem $(\delta(c)$ is higher), and health worsens on average with age for children at any income level. This implication hinges on the assumption that chronic conditions can only accumulate over time. It could be reversed if children were able to recover from some serious adverse health conditions.

(ii) Observed in the cross section, the gradient in the health-income relationship is steeper for older children than for younger children.

Shallower gradients for younger children appear for two related reasons. First, the probability of receiving a chronic condition is higher for poorer children, and the accumulation of these conditions over time will manifest itself in a steeper gradient. In addition, the erosion of poor children's health stock, after the arrival of a chronic condition, takes time. As shown in Figure 4.2, a poor child at age 1 with chronic condition $c_{1}$ is in better health than he will be at age 2 (the point in time when the erosion in his health elicits a large enough resource response to maintain his health at a particular level).

(iii) The impact of a health shock on children's health stock should depend upon the severity of the chronic condition contracted. For any given chronic condition, the children from wealthier families have a higher health stock and, if $\partial^{2} e(y, h) / \partial h \partial y<0$ at all $h$ and $y$, so that the slope of the investment function with respect to health is always steeper for wealthier families, then the difference in the health of rich and poor children will increase with the severity of the condition. 
As in Figure 4.1, at any value of $c$, children from wealthier families will have better health outcomes than will children from poorer families. Increases in $c$, which shift $\delta(c)$ up, will have a larger adverse effect on poor children than rich children.

In Section 5, we examine these implications of the model using data on children's health from the NHIS and the PSID. We also return to the question of whether current or long run income is more relevant for children's health status.

\section{Evidence on chronic conditions, income and cumulative health status}

For the purposes of testing the model laid out in Section 4, the NHIS and the PSID have different strengths. The NHIS has the advantage of being large, which is crucial for analyzing chronic conditions that are relatively rare. However, the NHIS is not a panel, and thus we cannot track parents, children or income through time. Because the PSID is a panel, we can use household incomes from all periods of a child's life to assess whether it is long run or current income that has the larger effect on health. We will make use of these data sets to test aspects of the model presented in Section 4.

\section{a. Chronic conditions, income and health}

The model predicts that the effect of a chronic condition on children's health stock should depend upon the severity of the chronic condition and, for any given chronic condition, children from wealthier families should have higher health stocks. In addition, if the slope of the investment function with respect to health is everywhere steeper for wealthier families, then the difference in the health of rich and poor children should increase with the severity of the condition.

To test these implications of the model, we regress an indicator of poor health on an indicator for the presence of a chronic condition, the log of family income, and the log of family income interacted with the indicator for the presence of that condition. Results of these regressions are presented in Table 3, where each row of the table presents results for a single 
chronic condition for 3 samples: all children, younger children (ages 0-8) and older children (ages 9-17). ${ }^{4}$ The last row shows results that use the full sample of children, using an indicator of whether the child had any of the 14 medical conditions.

Columns 2, 4 and 6 provide estimates of the change in the probability of reporting poor health with each condition, evaluated at median household income. The results show that conditions we would a priori label as more severe have the largest effect on children's health status: at median household income, the probability of poor health increases by 9 percent with asthma; 15 percent with diabetes; 21 percent with epilepsy; 19 percent with kidney disease; and 10 percent with mental retardation. Conditions we would a priori label as less severe have the smallest effect on children's health: at median household income the probability of poor health increases by 1 percent with hay fever and 2 percent with sinusitis.

For any given chronic condition, children from wealthier families have higher health stocks. This can be seen by inspection of columns 3, 5 and 7 of Table 3. For every condition, the interaction term between income and the chronic condition is negative and significant, with the exception of kidney disease. Children from wealthier families observed with chronic conditions are healthier than their counterparts in poorer families.

The gradient in health is largest for the most severe chronic conditions. That is, the protective effect of income is largest for the conditions that cause the greatest erosion to children's health status. The largest interaction terms are observed for asthma (-.048), diabetes (-.139), and epilepsy (-.077) — three of the chronic conditions that lead to the largest average

${ }^{4}$ We cannot include measures of all conditions in a single regression because families in the NHIS are assigned to one of 6 "condition lists" and provide information only on conditions covered by their assigned list. We used the NHIS-CH, which provides information on a large set of children's health conditions, to estimate a model that included a set of conditions and their interactions with income in a single regression. Because the sample is small and many conditions are rare, the coefficients were less precisely estimated than those shown in Table 3, but the general pattern of results is the same. 
deterioration of health status. (The only exception here is kidney disease, where the condition has a large and significant effect on health status, but income appears not to be protective.)

The model presented in Section 4 also predicts that the effect of income on health upon the arrival of a chronic condition should be larger, the longer the child had suffered from the chronic condition. In the NHIS we do not have information about the onset date of chronic conditions. However, we can examine the impact of the condition, and its interaction, at different ages observed in cross-section. If we assume that the deterioration of health status is cumulative, we would expect, even without information about the date of onset of particular conditions, that older children should experience more detrimental health outcomes due to chronic conditions, the lower is household income. We examine this hypothesis by estimating separate models for younger (aged 0 to 8 ) and older (aged 9 to 17) children. The results are in the last 4 columns of Table 3. Consistent with the model, we find that income is more protective of children's health status at older ages for almost every condition presented.

We take the results in Table 3 as evidence in support of the model's implication that chronic conditions interact with income and, in doing so, create a gradient in children's health. A second set of results consistent with this implication is provided in Table 4, where the number of bed days lost to illness and the number of hospitalization stays are used as alternative measures of poor health. The left panel of Table 4 presents results of regressions where the number of bed days is regressed against an indicator that the child has particular conditions, the log of family income, the log of family income interacted with these conditions. The first column in the panel presents the marginal effect of the condition on bed days, evaluated at median household income. The right panel provides an analogous set of results for hospitalization episodes.

Both panels provide evidence that income protects children with chronic conditions. Asthma provides a useful example. We find that the association between asthma and bed days and hospitalization at the $25^{\text {th }}$ percentile of income is much greater than that at the $75^{\text {th }}$ percentile of income: at the $25^{\text {th }}$ percentile (a log income level of 9.5) children with asthma spend 5.6 more 
days in bed than do children without asthma, and have 0.12 more hospital episodes, relative to 3.8 more bed days and 0.05 more hospital episodes for a child at the $75^{\text {th }}$ percentile of income. The final row of the table indicates that having at least one of the 14 chronic conditions is associated with significantly more bed days and hospitalization episodes, and that these effects are larger for poorer children.

\section{b. $\underline{\text { Current versus permanent income }}$}

The model in Section 4 left open the question of whether the timing of income over a child's life affects a child's health. One possibility is that investment decisions are made based on long run average income, in which case the timing is not important. Another possibility, which has been discussed in the child development literature, is that the effect of income depends on the age of the child when the income was received (Duncan et al. 1997). We use data from the PSID to examine whether the timing of income matters, exploiting the fact that we have information on the family's income throughout the child's lifetime (and indeed from the period before the child was born). The first panel of Table 5 presents the results of ordered probits of health status on the log of average income in different periods of life (ages 0 to 3, 4 to 8,9 to 12), and on the $\log$ of average income in the household in the six years before the child was born. Each column of Panel A presents the results of a different ordered probit.

We see in Table 5 that family income in the years before the child is born and those at different ages of life are all equally correlated with a child's current health status. Family income prior to the child's birth is significantly correlated with the child's current health, for children of all ages (columns 1, 4 and 8 of Panel A). Moreover, the coefficient on income prior to birth for children aged 0 to $3(-.137)$ is not significantly different from that on income during the years when the child is aged 0 to $3(-.160)$. The same pattern is seen for older children: the coefficient on income prior to birth for children aged 9 to $12(-.176)$ is not significantly different from that on income during ages 0 to $3(-.199)$, ages 4 to $8(-.195)$, or ages 9 to $12(-.236)$. 
These results are consistent with the hypothesis that long run average income determines health investments and health status at different ages. If this is true, the coefficients on income when the child was aged 0 to 3, for children now aged 4 or above, cannot be interpreted as the impact of income arriving during ages 0 to 3. For these older children, the coefficient on income from earlier ages (and indeed that before birth) just provides us with an estimate of the impact of permanent income on children's health at their current age.

We cannot reject that income at different ages have equal effects on a child's health status, and in the last three panels we impose their equality. We estimate ordered probits of health status on the log of average income for all years the child has been alive (birth year to 1997) in Panel B; on the log of average income from the six years prior to birth through 1997, in Panel C; and on the log of average income from the nine years prior to birth through 1997, in Panel D. Using income since birth, we find a significant relationship between income and health status that becomes more pronounced at older ages (the coefficient increases from -0.160 for the youngest children to -0.253 for children aged 4 to 8 , to -.297 for children aged 9 to 12 ). When we use income from six years prior to birth through to current age, these coefficients become larger in absolute value $(-.182,-.257-.344)$; our measure of permanent income becomes less noisy when we use these additional years of data. The coefficient estimates change very little with additional lags beyond that point (see the results when we add lags of income for seven to nine years before birth in Panel D). We take the evidence in Table 5 to suggest that children's health status is correlated with the household's permanent income, and that the impact of permanent income on a child's health status becomes larger, the older is the child.

The evidence in Tables 3 through 5 is consistent with the model put forward in Section 4. Children from families with lower incomes are at risk for worse health outcomes. The differences manifest themselves over time in childhood, and appear to work, at least in part, through chronic conditions. 


\section{Extensions and alternative explanations}

The results presented in Section 5 are consistent with a model in which permanent income affects children's health status through its effect on parental management of children's chronic conditions. However, they do not rule out many third factor explanations, such as a lasting effect of poor health at birth, or a spurious correlation between children's health and household income that derives from poor parental health. We evaluate these and other potential explanations in this section.

\section{a. Health at birth}

The model in section 4 includes the assumption that all children are born in excellent health. In fact, health at birth varies across children. Some children are born with health problems, such as prematurity, low birth weight for gestational age, or congenital birth defects.

There are several reasons to think that heterogeneity in health at birth could account for at least some of our earlier findings. First, it may be that children born to poorer women are at greater risk of being born with health problems, possibly due to poorer prenatal care, higher rates of maternal smoking that accompany lower income levels, or other maternal or environmental characteristics associated with low income. Poor birth health could therefore produce a gradient in health among very young children. Second, if poorer children are born with the most severe health problems, ones that require a longer recovery period or that result in chronic conditions, then the gap in health between rich and poor children might increase with age, as wealthier children who are born in poor health recover whereas poorer children who are born in poor health do not. Finally, holding constant the severity of health problems at birth, wealthier children may recover faster because their parents spend more on their care.

For policy purposes, it is important to examine whether health at birth accounts for a large part of the gradient between health and income in childhood. If so, it implies that equalizing the quality of prenatal health care and working to improve maternal health behaviors in the 
prenatal period may go a long way toward eliminating the gradients we observe throughout childhood.

Adding heterogeneity in health at birth does not fundamentally alter the model developed above. Health at birth can be broken into a component that is chronic, so that children can be born with different values of $c$, and a component that is transitory, so that given $c$ children can be born with non-steady state health levels below $h^{*}$. In this case, the model works as described above, with the only addition that children with transitory health problems at birth move, after the birth, to the steady state-level that coincides with their family income level and value of $c$.

We use data from the NHIS to examine whether health at birth accounts for the relationship between current health and current income. The core NHIS collects no information on health at birth. However, the NHIS-CH supplement collects information for one child per family on the child's birth weight and the number of nights the child spent in the hospital after the birth. In Table 6, we show results of order probits of current health status on poor health at birth, including interactions of poor birth health with age and income. We use, as an indicator of poor health at birth, that a child spent one week or longer in the hospital after birth and/or that the child was born at very low birth weight (less than 3.5 pounds). This assigns poor birth health to ten percent of our sample. (Results are similar using different cutoffs for poor birth health.)

The results indicate that poor birth health has larger adverse effects on children at low income levels, and that improvements with age are slower for poorer children. Column 2 shows that poor health at birth is positively related to poor health later in life, but that the effects of poor health at birth diminish with age. The addition of controls for poor health at birth has very little effect on the health-income gradient, or on our estimate of the rotation of the gradient with age. Results in column 2 also suggest that the adverse effects of poor health at birth on current health dissipate with age..$^{5}$ The third column includes an interaction of health at birth and income, and

${ }^{5}$ This is consistent with the findings of McCormick et al. (1993) but somewhat at odds with those of Currie and Hyson (1998).Currie and Hyson, using data from the British National 
indicates that poor birth health has a larger adverse effect on poorer children. In the fourth column, we examine the hypothesis that higher income children recover from poor health at birth more quickly than do poorer children, by including an interaction of age, poor health at birth, and income. (The birth health/income interaction is omitted, which imposes the implicit restriction that poor health at birth has identical effects on health status for poor and rich children at age 0 .) The parameter estimate for this interaction term is negative and marginally significant, indicating that the adverse effects of health at birth on current health decline more quickly with age for wealthier children. The final column shows results of an ordered probit that include a complete set of interactions of poor health at birth with age, income, and income times age. The parameter estimates are consistent with the hypothesis that wealthier children are less affected by poor health at birth, and recover more quickly. However, although the "health at birth" variables are jointly significant, with this number of interactions the individual parameters are not estimated precisely. Most important for our analysis, adding controls for birth health does not alter the basic finding that lower income is associated with worse health. Health at birth does not account for the income gradient in childhood health.

\section{b. Parental health as a determinant of children's health}

Children' health may also be affected by the health status of their parents, possibly through an inherited susceptibility to different diseases, a less healthy uterine environment, or lower quality care by sick parents. In addition, the health of parents and children might be affected by common but unmeasured environmental factors, resulting in a correlation between their health levels. It is also possible that parental health is a "third factor" that accounts for the income gradient in children's health: an income gradient in children's health might be observed if parents in poor

Child Development Survery (1958 birth cohort) find a significant effect of low birth weight on the probability a woman reports fair or poor health at age 23 , but not at age 33 , and a significant effect of low birth weight on the probability that men report fair or poor health at age 33, but not at age 23. It is possible that advances since 1958 in the medical treatment of low-birth-weight infants has altered the long-term effects of low birth weight. 
health have lower earnings, and poor health is transmitted from parents to children — producing a spurious correlation between income and children's health.

This line of reasoning might suggest that equations of the form shown in Table 2 should include controls for parental health. However, doing so has several potential pitfalls. If the health of parents is affected by their income levels (as is argued in much of the literature on socioeconomic status and health), and income is measured with error, then the "effects" of parental health may simply reflect the effects of income. In addition, if the health of both parents and children are affected by current and lagged values of income, the parental health may serve as a proxy for the income levels experienced by children at earlier ages. For both of these reasons, we cannot cleanly separate the effects of parent's health and family income on children's health.

Mindful of these problems, we estimate models identical to those in the lower panel of Table 2 but with additional controls for mothers' and fathers' health status, to see whether this eliminates the income gradient in health or the steepening of the gradient with age. The results are shown in Table 7. The top panel presents results for the NHIS in which indicator variables are included for whether the child's mother and father are in excellent or very good health. The bottom panel presents analogous results for the PSID. Because the PSID is a panel, we can also test whether results are more robust when using long run average income, in place of current income. There are several key findings. First, there are large "effects" of parent's health on children's health. For example, if a child aged 0-3 has a mother in very good or excellent health, his or her chance of also being in very good or excellent health rises by $27 \%$ (estimate not reported in Table 7). The corresponding increase associated with having a father in very good or excellent health is $16 \%$. Second, mother's health is more strongly associated with children's health than is father's health, which is consistent with the idea that women in worse health bear less healthy children, or that poor health in women makes them less able care givers. ${ }^{6}$

${ }^{6}$ We also estimated regressions with a complete set of dummies for parental health (along a 5-point scale). There is a non-monotonic relationship between mother's health status and that of 
Third, the inclusion of controls for parents' health reduces the coefficients on family income. For children in the oldest age group, the coefficient on family income in an ordered probit of health status declines from -.218 when no health variables are included (lower panel of Table 2 ), to -.125 when indicators of whether parent's health is excellent or very good are included. However, these estimates are still large and highly significant. In addition, the gradients in income still increase substantially with the age of the child, whereas the gradients in parental health do not. Controlling for parental health status does not eliminate the rotation of the gradient with age.

The results in the lower panel, using the PSID, provide evidence that some of the decline in the coefficients for family income may be because parental health is a proxy for permanent or long-run income. As was true for the NHIS, when controls for parental health are added, the coefficients on current family income decline (columns 1, 3 and 5.) However, when long run income is substituted for current income, the coefficients on family income return to values that are similar to those in Table 5. Although parental health (and especially maternal health) is associated with child health, it does not account for the relationship between long-run income and child health.

\section{c. Genetic ties}

The powerful connection between parents' health status and children's health status leads us to ask whether permanent income is simply proxying for a genetic tie between parents and children. A simple genetic story is that parents who are healthier have healthier children, and also earn more money because of their better health endowments. We use information on adoptive versus biological parents (available in the NHIS-CH) to test this hypothesis. Provided that wealthier adoptive parents are not in a position to select healthier infants, we should find a significant

children aged 0 to 3: as one moves from "fair" to "poor" health of the mother, the child's health status improves. Perhaps when mother's health is especially poor fathers play a bigger role in children's health provision. 
income gradient in the health of birth children, but little gradient in the health of adopted children, if a simple genetic story is driving our results. Panel A of Table 8 shows estimates of ordered probits identical to those in Table 2 (using Controls 2), but on the smaller NHIS-CH sample. As before, we find an income gradient in health that increases with age. The ordered probits in Panel B add a complete set of indicators for family type: birth mother and father, birth mother and other father, birth mother only, other mother only, other mother and birth father, birth father only, other father only, or two non-birth parent, and each of these controls interacted with the log of family income. We present in the table the coefficients for two polar cases: the income effect for a child living with both birth parents, and the income effect for a child living with two non-birth parents. For no age group is there a significant difference in the impact of income based on parental type and, for three of the four age groups, the impact of income is larger for children living with nonbirth parents. We cannot reject equality of the eight incomexparental type coefficients for any age group. These results cast doubt on the simple genetic story.

\section{d. Health and health insurance}

The model in section 4 predicts that parental investments, interacting with accumulated chronic conditions, are key determinants of childhood health status. If investment is comprised mainly of medical expenditure, then access to health insurance might be an important determinant of health status. ${ }^{7}$ Our finding that poorer children have worse health given specific chronic conditions could be due to poorer children having no insurance coverage, or insurance coverage that pays for lower quality care.

The NHIS-CH contains information on whether the child was covered by Medicaid or other health insurance, and we use these data to examine whether the relationships between income, chronic conditions, and health status are altered when we include controls for insurance.

${ }^{7}$ Although not all children with insurance receive identical medical care. For example, Currie and Thomas (1995) find significant differences in doctors visits for illness between white and black children covered by Medicaid. 
Table 9 shows ordered probit estimates of health status on income, controlling for whether the child has had one of a number of medical conditions included in the 1988 NHIS child health supplement (listed in the footnote to the table), interactions of income and the condition measure, and controls for insurance. The second column indicates that children with insurance-either private insurance or Medicaid — are in significantly better health. The point estimate indicates that in the absence of any medical conditions, being insured has the same effect on health status as a $54 \%$ increase in income. However, adding the insurance measure does not alter the estimated effects of income on health. The third column adds an interaction of the indicators for whether the child is insured and whether he or she has an adverse medical condition. This coefficient should be negative if families with insurance are better equipped to deal with medical problems. Instead, it is positive and imprecisely estimated.

This anomalous result could be due to the fact that the insurance measure includes Medicaid, and a child on Medicaid may have worse health for a variety of other reasons. (The parents of poor children may learn that their children are eligible for Medicaid only when the children are sick and presented for treatment.) In the fourth column we add an indicator for whether the child receives Medicaid, and an interaction of Medicaid with the condition indicator. We find that adding these controls for Medicaid does not alter the previous finding that insurance does nothing to improve the health of children with adverse medical conditions. In addition, the results indicate that children who are insured and receive Medicaid have worse health status than those who have private insurance, and the hypothesis that the net effect of medicaid on health is zero (given no adverse medical conditions) cannot be rejected. ${ }^{8}$ Children who receive Medicaid and have a medical condition have significantly worse health status than those with no insurance and a medical condition $(F$-statistic $=4.41, p$-value $=.04)$. It seems implausible that Medicaid actually damages children's health (see Currie and Gruber 1996 on the beneficial impact of Medicaid expansions on infant mortality rates) and we think the more likely explanation for this

\footnotetext{
${ }^{8}$ The net effect of having Medicaid when there are no adverse health conditions is -.1171 $+.0754=-.0417$. The F-statistic for the test that this effect equals zero is .79 (p-value $=.38$ ).
} 
result is that Medicaid is correlated with unmeasured family characteristics that are related to poor health outcomes. For our purposes, the important finding is that controlling for insurance does not substantially alter the estimated effects of income on health.

\section{e. Children's health and maternal labor supply}

Another possible explanation for the income gradient in children's health is that the parents of less-healthy children reduce their labor supply, producing a positive correlation between low income and poor health. Our earlier results suggest that this is unlikely to provide a complete explanation of our findings: incomes from before the child was born were seen to have as strong an effect on children's health status in the PSID as income in any period of a child's life. In the NLSY, children observed in low income families in the initial period were significantly more likely to experience a decline in health status between interviews. We provide additional evidence here, using data from the PSID to examine the impact of a child's poor health at birth on subsequent maternal labor supply. We look at maternal labor supply during the first three years of a child's life, since our earlier results indicate that poor health at birth carries over into poor health in this time period. The PSID has information on whether the child was born at low weight (5.5 pounds or less) or spent time in a neonatal intensive care unit, which we use to construct an indicator of poor health at birth.

Table 10 shows regressions of an indicator of mothers' employment status (top panel) and hours worked (bottom panel) on the indicator of the child's health at birth. These results provide strong evidence that poor health at birth does not affect maternal labor supply. Mothers of infants with health problems are not significantly less likely to work in the first three years of the child's life, and do not have significantly fewer work hours. In the first regression on each panel, the coefficient on the indicator of poor health at birth is typically positive, although not significantly different from zero. The second column of each panel indicates that whether a woman worked in the year prior to the birth is an important determinant of whether and how much a mother works in the first three years after the birth. However, as indicated in the third column of each panel, of 
mothers who worked prior to the child's birth, there is no significant difference in work status and work hours of those who did and did not have a child with poor health at birth. Our conclusion is that the positive relationship between income and health in childhood is not due to the poor health of children reducing family income.

\section{Conclusions: mechanisms and implications}

We have shown that the relationship between income and health status observed for adults has antecedents in childhood. A family's long-run average income is a powerful determinant of children's health status, one that works in part to protect children's health upon the arrival of chronic conditions. The health of children from families with lower incomes erodes faster with age, and these children enter adulthood with both lower socioeconomic status and poorer health.

An important priority for future research is to identify the mechanisms that underlie the relationship between income and children's health. We have been able to rule out several possible mechanisms: insurance does not play a crucial role in protecting health upon the arrival of a chronic condition, health in childhood does not appear to be a persistent reflection of health at birth, and a simple genetic model cannot explain the association between health and income.

Several additional avenues warrant further investigation. One is to examine the relationship between family income, parental health behaviors, and children's health. Table 11 presents preliminary results of ordered probits in which a child's health status is modeled as a function of the log of family income and a number of health behaviors, including whether the child has a regular bedtime, whether someone in the household smokes, whether the child wears a seatbelt all or most of the time, whether the child has a place for routine medical care and a place for sick care, and whether the child has had a routine doctor's visit in the past year. Jointly, these variables are highly correlated with children's health status. However, they do not affect the coefficient on log income, perhaps because the gradient shows the cumulative effect of such behaviors over a lifetime, and not just at a point in time. Some of these behaviors - particularly regular bedtimes and wearing seatbelts — are highly correlated with children's health status. It seems unlikely that seatbelt use directly affects the child's health (short of having an accident), but 
that both seatbelt use and regular bedtimes are correlated with stability in household life. Future work will focus on factors that we can not examine in the data sets here, but which may be related — including such parental behaviors as staying home with children when the children are sick, getting them to a doctor in a timely fashion when they fall ill, and overseeing the children's meals on a daily basis. The link between income, nutrition, and children's health outcomes may also prove to be important.

The results in this paper highlight the role of chronic conditions in the relationship between income and health. It may be that higher-income parents are better able to manage chronic health problems. For example, socioeconomic status has been implicated as a determinant of adherence to and compliance with treatments for childhood epilepsy (Snodgrass et al. 2001) and diabetes (Thompson et al. 2001, Davis et al. 2001).

What are the implications of poor health in childhood? In addition to the direct welfare and financial costs of illness, poor childhood health results in lower levels of human capital accumulation. Less healthy children spend more days in bed and miss more school. In addition, we use the NHIS-CH to show that childhood illness results in children falling behind in school, especially for children who are poor. Table 12 presents regressions of years of completed education on a complete set of age dummies, income, whether the child has one of the medical conditions defined in the footnote to table 9, and interactions of income and the condition indicator. The first three columns show results for children aged 5 to 17 . These results indicate that having a condition reduces years of education, but that it does so less for children with higher incomes. In addition, the greater adverse effect of having a medical condition for poorer children grow larger as the child becomes older. This is shown in column 3, where the coefficient on the interaction term between income, age, and the condition indicator is positive. It can also be seen from the final two columns that show separate results for 5 to 11 year-olds and 12 to 17 yearolds: the positive effect of income on education when a condition is present is more than 4 times larger for the older age group. Poorer children arrive at the doorstep of adulthood with lower health status and with less education. It is an open question whether these factors result in lower earnings as adults - contributing to the gradients observed in adulthood. 


\section{References}

Adler, Nancy E., Thomas Boyce, Margaret A. Chesney, Sheldon Cohen, Susan Folkman, Robert L. Kahn, and S.Leonard Syme, 1994. "Socioeconomic Status and Health, The Challenge of the Gradient,"American Psychologist, 15-24.

Currie, Janet and Jonathan Gruber. 1996. "Health Insurance Eligibility, Utilization of Medical Care, and Child Health.” Quarterly Journal of Economics 111, 431-466.

Currie, Janet and Duncan Thomas. 1995. "Medical Care for Children: Public Insurance, Private Insurance, and Racial Differences in Utilization," The Journal of Human Resources 30, 135-62.

Currie, Janet and Rosemary Hyson. 1998. "Is the Impact of Health Shocks Cushioned by SocioEconomic Status? The Case of Low Birthweight." mimeo. UCLA, December.

Dadds, Mark R., Ruth E. K. Stein, and Ellen Johnson Silver. 1995. "The Role of Maternal Psychological Adjustment in the Measurement of Children's Functional Status.” Journal of Pediatric Psychology 20(4), 527-544.

Davis, Catherine L., Alan M. Delamater, Kimberly H. Shaw, Annette M. La Greca, Margaret S. Eidson, Jose E. Perez-Rodriguez, Robin Nemery. 2001. "Parenting Styles, Regimen Adherence, and Glycemic Cnotrol in 4- to 10-Year-Old Children With Diabetes." Journal of Pediatric Psychology 26(2), 123-129.

Duncan, G. J. and J. Brooks-Gunn, Eds. 1997. Consequences of Growing Up Poor. New York: Russell Sage Foundation Press.

Fan, Jianqing, 1992. "Design-Adaptive Nonparametric Regression." Journal of the American Statistical Association 87, 998-1004.

Fuchs, Victor R. 1982. “Time Preference and Health: An Exploratory Study.” In Fuchs, V.R (ed.) Economic Aspects of Health, Chicago: University of Chicago Press. 93-120.

Halfon, Neal and Paul W. Newacheck, 1993. "Childhood Asthma and Poverty: Differential Impacts and utilization of Health Services." Pediatrics 91(1), 56-61.

Idler, Ellen L. and Stanislav V. Kasl. 1995. "Self-Ratings of Health: Do They Also Predict Change in Functional Ability?" Journal of Gerontology: Social Sciences 508(6): S344-S353.

Korenman, Sanders and Jane E. Miller. 1997. "Effects of Long-Term Poverty on Physical Health of Children in the National Longitudinal Study of Youth." Chapter 7 in G. Duncan and J. Brooks-Gunn, eds. Consequences of Growing Up Poor. New York: Russell Sage Foundation.

Marmot, Michael, 1999. "Epidemiology of Socioeconomic Status and Health: Are Determinants Within Countries the Same as Between Countries?" in Nancy E. Adler, Michael Marmot, Bruce S. McEwen and Judith Stewart (eds.), Socioeconomic Status and Health in Industrial Nations, New York: The New York Academy of Sciences. 
McCormick, Marie C., Jeanne Brooks-Gunn, Kathryn Workman-Daniels, and George J. Peckham. 1993. "Maternal Rating of Child Health at School Age: Does the Vulnerable Child Syndrome Persist?" Pediatrics 92(3), 380-388.

Newacheck, PW. 1994. "Poverty and Childhood Chronic Illness." Archives of Pediatric and Adolescent Medicine, 148, 1143-1149.

Snodgrass S.R., V.V. Vedanarayanan, C.C. Parker and B.R. Parks. 2001. "Pediatric Patients with Undetectable Anticonvulsant Blood Levels: Comparison with Compliant Patients." Journal of Child Neurology, 16(3), 164-8.

Thompson, SJ, WF Auslander, and NH White. 2001. "Comparison of Single-Mother and TwoParent Families on Metabolic Control of Children With Diabetes." Diabetes Care 24(2), 234-238.

Smith, James P, 1999, "Healthy Bodies and Thick Wallets: The Dual Relation Between Health and Economic Status." Journal of Economic Perspectives, 13(2). 145-167.

West, Patrick. 1997. "Health Inequalities in the Early Years: Is There Equalisation in Youth?" Social Science and Medicine 44(6), 833-58. 


\section{Appendix}

National Health Interview Survey 1986-1995

The NHIS asks a knowledgeable household member to report on the health status and health conditions of children aged 0 to 17. Each household was randomly assigned to answer questions from one of six "conditions lists," and information was collected on whether each household member had experienced each of the medical conditions on the assigned condition list. (The NHIS was substantially redesigned after 1995, which limits us to the period 1986-1995.)

We start with 314455 children aged 0 to 17, and drop 43707 cases (14 percent) for whom household income is not reported. After removing these observations, we also exclude children who fall into the following categories: (1) We deliberately exclude children when there is doubt about whether reported household income adequately reflects the income over which the child may have a claim. Thus we remove from our analysis children who, at the time of the interview, were not living with at least one of their parents (5483 cases). (2) We remove children who were not the sons or daughters of the reference person or spouse (18608 children). Our concern with including children residing with a grandparent head of household (the largest alternative to residing with a parental head-13741 cases) is that we do not know how long the child has lived with the grandparent, and we may be falsely assigning to the child income that does not reflect the income in which the child has a share, or has had a share for an unknown period of time. (3) We remove children in households containing more than one family (899 children), and children who are not members of the "primary family" within the household (2382 children). (4) We remove 5095 children from households where children in the households are reported to be of different races. (Difference in race within a sibship may reflect children having fathers of different races, and we would not choose to remove such children just for this reason. However, difference in reported race may also be due to measurement error, or to children being fostered.) (5) We are also interested in whether our results are robust to the inclusion (exclusion) of controls for parental and household characteristics that might have independent effects of children's health (family size; race; mothers' age, education and an unemployment indicator if she is present; fathers' age, education and an unemployment indicator if he is present), and we restrict our core sample to children for whom this information is available. Our core sample of children from the NHIS is 229,330 observations. When we turn to the analysis of (sometimes rare) medical conditions, we use the full sample of all children with non-missing information on income, family size, race, age and gender.

\section{Assignment of household income}

The NHIS contains information on total household income for 27 income categories, in $\$ 1000$ intervals between an income of $\$ 0$ and $\$ 20,000$, and in $\$ 5000$ intervals between $\$ 20,000$ and $\$ 50,000$. All household incomes above $\$ 50000$ are top coded. We assign incomes to these income categories using data from the 1986-1995 March Current Population Surveys. Specifically, we calculate, for each income category in each year, the mean total household income in the CPS for households whose head's education matches that of the reference person in the household and whose income falls into that income category. For households containing both a reference person and spouse, we used the education of the male (whether he was the reference person or not) to match income information across the data sets.

\section{Definitions of medical conditions:}

The conditions we use are drawn from 5 of the 6 "condition lists" in the National Health Interview Survey. The following table maps the NHIS condition codes and definitions into the definitions we use: 


\begin{tabular}{|c|c|c|}
\hline Chronic condition & Code & Definition \\
\hline Vision problem & $\begin{array}{l}201 \\
202 \\
240 \\
241 \\
242 \\
243\end{array}$ & $\begin{array}{l}\text { blind - both eyes } \\
\text { other visual impairments } \\
\text { tinnitus } \\
\text { cataracts } \\
\text { glaucoma } \\
\text { diseases of the retina }\end{array}$ \\
\hline Hearing problem & $\begin{array}{l}203 \\
204\end{array}$ & $\begin{array}{l}\text { deaf - both ears } \\
\text { other hearing impairments }\end{array}$ \\
\hline Retardation & 208 & mental retardation \\
\hline Deformity & $\begin{array}{l}209 \\
210 \\
211 \\
212 \\
213 \\
214 \\
215 \\
216 \\
217 \\
218 \\
219 \\
220 \\
221 \\
222 \\
223 \\
224 \\
225 \\
226 \\
227 \\
228 \\
229 \\
230 \\
231 \\
232 \\
233 \\
234 \\
235 \\
236 \\
237 \\
238\end{array}$ & $\begin{array}{l}\text { absence - both arms/hands } \\
\text { absence - one arm/hand } \\
\text { absence - fingers, one or both hands } \\
\text { absence - one or both legs } \\
\text { absence - feet/toes, one or both limbs } \\
\text { absence - lung } \\
\text { absence - kidney } \\
\text { absence - breast } \\
\text { absence - bone, joint, muscle of extremity } \\
\text { absence - tips of fingers, toes } \\
\text { paralysis of entire body } \\
\text { paralysis of one side of body - hemiplagia } \\
\text { paralysis of both legs - paraplegia } \\
\text { other total paralysis } \\
\text { partial paralysis - cerebral palsy } \\
\text { partial paralysis - one side of body only - hemiparesis } \\
\text { partial paralysis - legs - both or paraparesis } \\
\text { other partial paralysis } \\
\text { paralysis - complete or partial - other site } \\
\text { curvature/deformity of back or spine } \\
\text { orthopedic impairment of back } \\
\text { spina bifida } \\
\text { orthopedic impairment of hands, fingers only } \\
\text { orthopedic impairment ofshoulders } \\
\text { other orthopedic impairment of upper extremities } \\
\text { flatfeet } \\
\text { clubfeet } \\
\text { other orthopedic impairment of lower extremities } \\
\text { other deformities/orthopedic impairments } \\
\text { cleft palate }\end{array}$ \\
\hline
\end{tabular}




\begin{tabular}{|c|c|c|}
\hline Chronic condition & Code & Definition \\
\hline Digestive problem & $\begin{array}{l}301 \\
302 \\
303 \\
304 \\
305 \\
306 \\
307 \\
308 \\
309 \\
310 \\
311 \\
312 \\
313 \\
314 \\
315\end{array}$ & $\begin{array}{l}\text { gallbladder stones } \\
\text { liver diseases including cirrhosis } \\
\text { gastric ulcer } \\
\text { duodenal ulcer } \\
\text { peptic ulcer } \\
\text { hernia of abdominal cavity } \\
\text { disease of the esophagus } \\
\text { gastritis and duodenitis } \\
\text { indigestion } \\
\text { other functional disorders of stomach and digestive system } \\
\text { enteritis and colitis } \\
\text { spastic colon } \\
\text { diverticula of intestines } \\
\text { constipation } \\
\text { other stomach and intestinal disorders }\end{array}$ \\
\hline Diabetes & 403 & diabetes \\
\hline Epilepsy & 405 & epilepsy \\
\hline $\begin{array}{l}\text { Frequent } \\
\text { headaches }\end{array}$ & $\begin{array}{l}406 \\
407\end{array}$ & $\begin{array}{l}\text { migraine headache } \\
\text { other headache }\end{array}$ \\
\hline Kidney disease & $\begin{array}{l}409 \\
410 \\
411\end{array}$ & $\begin{array}{l}\text { kidney stone } \\
\text { kidney infections } \\
\text { other kidney trouble }\end{array}$ \\
\hline Heart disease & $\begin{array}{l}501 \\
502 \\
503 \\
504 \\
505 \\
506 \\
507\end{array}$ & $\begin{array}{l}\text { rheumatic fever with or w/o heart disease } \\
\text { ischemic heart disease } \\
\text { tachycardia or rapid heart } \\
\text { heart murmurs } \\
\text { other unspecified heart rhythm disorders } \\
\text { congenital heart disease } \\
\text { other selected types of heart disease }\end{array}$ \\
\hline Bronchitis & 601 & bronchitis \\
\hline Asthma & 602 & asthma \\
\hline Hayfever & 603 & hayfever \\
\hline Sinusitis & 605 & sinusitis \\
\hline
\end{tabular}

\section{National Health and Nutrition Examination Survey}

We restrict our sample to children whose survey information was given by a parent, and whose household reference person was either that parent or a spouse. Family income is measured within twenty $\$ 1000$ brackets between $\$ 0$ and $\$ 19,999$ per year, $\$ 5000$ brackets between $\$ 20,000$ and $\$ 49,999$, and one bracket for $\$ 50,000$ and above. The survey was conducted over the course of six years, but families are only identified as being surveyed in the first or second three-year period. The average annual inflation rate of 3.8 percent that prevailed during this period is likely to introduce a moderate degree of measurement error in measures of real income. We assign families to the midpoint of their income interval and adjust for the difference in the average price level between the first and second half of the survey. 


\begin{tabular}{|c|c|c|c|}
\hline & NHIS & PSID & NHANES III \\
\hline Age & 8.31 & 6.29 & 5.47 \\
\hline Income $(\$ 1997)$ & 48,343 & 47,525 & 32,192 \\
\hline Health status & 1.687 & 1.701 & $\begin{array}{c}\text { parent: } 1.995 \\
\text { physician: } 1.401\end{array}$ \\
\hline Health status very good or excellent & 0.807 & 0.824 & $\begin{array}{c}\text { parent: } 0.674 \\
\text { physician: } 0.863\end{array}$ \\
\hline Health status fair or poor & 0.026 & 0.023 & $\begin{array}{l}\text { parent: } 0.073 \\
\text { physician: } 0.006\end{array}$ \\
\hline Bed days (past year) & 2.88 & & \\
\hline Restricted activity days (past 14 days) & 0.362 & & \\
\hline Hospitalization episodes (past year) & 0.042 & & \\
\hline $\begin{array}{l}\text { Missed school days due to illness (past } 14 \\
\text { days), aged } 5 \text { and older }\end{array}$ & 0.189 & & \\
\hline Male & 0.513 & 0.516 & 0.492 \\
\hline White & 0.779 & 0.524 & 0.662 \\
\hline Black & 0.149 & 0.424 & 0.299 \\
\hline Mother present in family & 0.987 & 0.932 & \\
\hline Father present in family & 0.810 & 0.643 & \\
\hline Household reference person is a woman & & & 0.319 \\
\hline Mother's age (if present) & 34.77 & 33.31 & age of reference \\
\hline Father's age (if present) & 37.57 & 36.27 & \\
\hline Mother's education (if present) & 12.69 & 13.14 & $\begin{array}{l}\text { education of } \\
\text { reference person }\end{array}$ \\
\hline Father's education (if present) & 13.15 & 13.33 & 11.46 \\
\hline Number of observations & 229330 & 2950 & 10018 \\
\hline
\end{tabular}

Notes: Health status is on a five-point scale: 1=Excellent, 2=Very Good, 3=Good, 4=Fair, 5=Poor. The means presented in the table are unweighted. The NHANES collects information on a smaller number of household characteristics than the NHIS and PSID. 
Table 2: Health status and $\ln$ (family income). NHIS and NHANES

\begin{tabular}{|c|c|c|c|c|c|c|c|c|}
\hline \multirow[b]{2}{*}{ ages } & \multicolumn{4}{|c|}{$\begin{array}{l}\text { Health Status ( } 1=\text { excellent, } 5=\text { poor }) \\
\text { Ordered Probits }\end{array}$} & \multirow{2}{*}{$\begin{array}{c}\begin{array}{c}\text { Bed } \\
\text { days }\end{array} \\
0-17\end{array}$} & \multirow{2}{*}{$\begin{array}{c}\begin{array}{c}\text { Restricted } \\
\text { activity } \\
\text { days }\end{array} \\
0-17\end{array}$} & \multirow{2}{*}{$\begin{array}{c}\text { Hospital } \\
\text { episodes }\end{array}$} & \multirow{2}{*}{$\begin{array}{c}\begin{array}{c}\text { Missed } \\
\text { school } \\
\text { days }\end{array} \\
5-17\end{array}$} \\
\hline & $0-3$ & $4-8$ & $9-12$ & $13-17$ & & & & \\
\hline obs & 51,448 & 54,067 & 64,746 & 59,069 & 229650 & 229650 & 229650 & 164327 \\
\hline \multicolumn{9}{|c|}{ NHIS Controls 1} \\
\hline $\begin{array}{l}\ln \text { (family } \\
\text { income) }\end{array}$ & $\begin{array}{l}-.183 \\
(.008)\end{array}$ & $\begin{array}{l}-.244 \\
(.008)\end{array}$ & $\begin{array}{l}-.286 \\
(.008)\end{array}$ & $\begin{array}{l}-.323 \\
(.008)\end{array}$ & $\begin{array}{l}-.096 \\
(.031)\end{array}$ & $\begin{array}{l}-.030 \\
(.005)\end{array}$ & $\begin{array}{l}-.0079 \\
(.0009)\end{array}$ & $\begin{array}{l}-.021 \\
(.003)\end{array}$ \\
\hline \multicolumn{9}{|c|}{ NHIS Controls 2} \\
\hline $\begin{array}{l}\ln \text { (family } \\
\text { income) }\end{array}$ & $\begin{array}{l}-.114 \\
(.008)\end{array}$ & $\begin{array}{l}-.156 \\
(.008)\end{array}$ & $\begin{array}{l}-.187 \\
(.008)\end{array}$ & $\begin{array}{l}-.218 \\
(.009)\end{array}$ & $\begin{array}{l}-.198 \\
(.035)\end{array}$ & $\begin{array}{l}-.036 \\
(.005)\end{array}$ & $\begin{array}{l}-.0078 \\
(.0009)\end{array}$ & $\begin{array}{l}-.019 \\
(.003)\end{array}$ \\
\hline $\begin{array}{l}\text { mother's } \\
\text { ed=12 yrs }\end{array}$ & $\begin{array}{l}-.136 \\
(.018)\end{array}$ & $\begin{array}{l}-.169 \\
(.018)\end{array}$ & $\begin{array}{l}-.170 \\
(.017)\end{array}$ & $\begin{array}{l}-.170 \\
(.017)\end{array}$ & $\begin{array}{l}.111 \\
(.075)\end{array}$ & $\begin{array}{l}-.011 \\
(.011)\end{array}$ & $\begin{array}{l}-.0021 \\
(.0020)\end{array}$ & $\begin{array}{l}-.008 \\
(.007)\end{array}$ \\
\hline $\begin{array}{l}\text { mother's } \\
\text { ed> } 12 \text { yrs }\end{array}$ & $\begin{array}{l}-.244 \\
(.021)\end{array}$ & $\begin{array}{l}-.322 \\
(.020)\end{array}$ & $\begin{array}{l}-.336 \\
(.019)\end{array}$ & $\begin{array}{l}-.319 \\
(.019)\end{array}$ & $\begin{array}{c}.319 \\
(.082)\end{array}$ & $\begin{array}{c}.001 \\
(.012)\end{array}$ & $\begin{array}{l}-.0029 \\
(.0022)\end{array}$ & $\begin{array}{l}-.018 \\
(.008)\end{array}$ \\
\hline $\begin{array}{l}\text { father's } \\
\text { ed=12 yrs }\end{array}$ & $\begin{array}{l}-.148 \\
(.020)\end{array}$ & $\begin{array}{l}-.162 \\
(.020)\end{array}$ & $\begin{array}{l}-.169 \\
(.019)\end{array}$ & $\begin{array}{l}-.166 \\
(.019)\end{array}$ & $\begin{array}{l}.154 \\
(.078)\end{array}$ & $\begin{array}{c}.015 \\
(.012)\end{array}$ & $\begin{array}{l}.0042 \\
(.0021)\end{array}$ & $\begin{array}{l}.005 \\
(.007)\end{array}$ \\
\hline $\begin{array}{l}\text { father's } \\
\text { ed>12 yrs }\end{array}$ & $\begin{array}{l}-.283 \\
(.022) \\
\end{array}$ & $\begin{array}{r}-.298 \\
(.021) \\
\end{array}$ & $\begin{array}{l}-.311 \\
(.020) \\
\end{array}$ & $\begin{array}{l}-.306 \\
(.020) \\
\end{array}$ & $\begin{array}{l}.317 \\
(.083)\end{array}$ & $\begin{array}{c}.038 \\
(.013) \\
\end{array}$ & $\begin{array}{c}.0040 \\
(.0022) \\
\end{array}$ & $\begin{array}{c}.012 \\
(.007)\end{array}$ \\
\hline
\end{tabular}

NHANES Controls 3

\begin{tabular}{lcccccccc}
\hline \hline & \multicolumn{3}{c}{$\begin{array}{c}\text { Parent-assessed health status } \\
\text { (Ordered Probits) }\end{array}$} & \multicolumn{4}{c}{$\begin{array}{c}\text { Physician-assessed health status } \\
\text { (Ordered Probits) }\end{array}$} \\
\hline \hline age & $0-3$ & $4-8$ & $9-12$ & $13-17$ & $0-3$ & $4-8$ & $9-12$ & $13-16$ \\
obs. & 4364 & 2913 & 1597 & 1144 & 4364 & 2913 & 1597 & 1144 \\
\cline { 2 - 5 } \cline { 8 - 10 } ln(family & -.160 & -.176 & -.202 & -.230 & -.051 & -.071 & -.102 & -.075 \\
income) & $(.025)$ & $(.030)$ & $(.041)$ & $(.046)$ & $(.030)$ & $(.036)$ & $(.046)$ & $(.053)$ \\
\hline \hline
\end{tabular}

Notes on the NHIS results: The numbers in parentheses are robust standard errors, where correlation is allowed between unobservables for observations from the same household. For rows labeled "controls 1," each regression included complete sets of age and year dummies; the logarithm of family size; indicators variables for whether the child has a mother in the household, has a father in the household, is male, is black, is white; interactions of the indicator for whether a mother (father) is in the household with mother's (father's) age; indicators for whether both the mother and father were respondents to the health survey, whether the father and not the mother was a respondent to the health survey, and whether neither the mother nor father were respondents to the health survey (the excluded category is that the mother but not the father was the respondent.) For rows labeled "controls 2," all variables in "controls 1" are included plus the measures of the mother's (father's) schooling shown in the table and indicators of whether the mother (father) is unemployed, where each education and unemployment variable is interacted with an indicator of whether the mother (father) is in the household. The sample is restricted to children age 17 or younger, who come from singlefamily households, who are members of the "primary family" in the household, who are children of either the reference person or spouse of reference person, who are of the same race as other children in the household, and who have non- 
missing values for all of the variables included in the regression. All children in a household are removed if any children in the household are removed. Total sample size is 229,330 .

Notes on the NHANES III results: The numbers in parentheses are standard errors. "Controls 3" includes an indicator for whether the family was in the highest income bracket, whether the child is white or black, male, whether the mother reported for the child, whether the person was sampled in 1988-1991, a complete set of dummies for the child's age, the logarithm of family size, whether the household reference person is a woman, and the reference person's age and marital status. Cases are dropped if the survey respondent was not a parent of the child, or if the respondent was not the household reference person or married to the reference person. 
Table 3: Regressions of poor health indicator (health status $=4$ or 5$)$ on $\ln (y)$, a specific health condition, and the interaction of income and the health condition. 1986-1995 NHIS.

\begin{tabular}{|c|c|c|c|c|c|c|c|}
\hline \multirow[b]{2}{*}{ Condition } & \multirow[b]{2}{*}{$\begin{array}{l}\text { Mean of } \\
\text { condition }\end{array}$} & \multicolumn{2}{|c|}{ Ages 0-17 } & \multicolumn{2}{|c|}{ Ages $0-8$} & \multicolumn{2}{|c|}{ Ages 9-17 } \\
\hline & & $\frac{\partial{\text { (health })^{*}}^{(\text {cond. })}}{\partial(\text { on }}$ & $\begin{array}{l}\text { cond'n } \\
\mathrm{x} \ln (\mathrm{y})\end{array}$ & $\frac{\partial(\text { health })^{*}}{\partial(\text { cond. })}$ & $\begin{array}{l}\text { cond'n } \\
\mathrm{x} \ln (\mathrm{y})\end{array}$ & $\frac{\partial \text { (health) }^{*}}{\partial \text { (cond. })}$ & $\begin{array}{l}\text { cond'n } \\
\mathrm{x} \ln (\mathrm{y})\end{array}$ \\
\hline $\begin{array}{l}\text { hay fever } \\
\text { (obs }=43,493)\end{array}$ & .0648 & $\begin{array}{l}.013 \\
(.004)\end{array}$ & $\begin{array}{l}-.012 \\
(.006)\end{array}$ & $\begin{array}{l}.027 \\
(.008)\end{array}$ & $\begin{array}{l}-.013 \\
(.010)\end{array}$ & $\begin{array}{l}.006 \\
(.005)\end{array}$ & $\begin{array}{l}-.007 \\
(.007)\end{array}$ \\
\hline $\begin{array}{l}\text { bronchitis } \\
(\mathrm{obs}=43,493)\end{array}$ & .0561 & $\begin{array}{l}.050 \\
(.005)\end{array}$ & $\begin{array}{l}-.030 \\
(.008)\end{array}$ & $\begin{array}{l}.052 \\
(.007)\end{array}$ & $\begin{array}{l}-.027 \\
(.010)\end{array}$ & $\begin{array}{c}.049 \\
(.008)\end{array}$ & $\begin{array}{l}-.038 \\
(.012)\end{array}$ \\
\hline $\begin{array}{l}\text { asthma } \\
(\text { obs }=43,493)\end{array}$ & .0629 & $\begin{array}{l}.092 \\
(.006)\end{array}$ & $\begin{array}{l}-.048 \\
(.007)\end{array}$ & $\begin{array}{l}.094 \\
(.009)\end{array}$ & $\begin{array}{l}-.042 \\
(.010)\end{array}$ & $\begin{array}{l}.090 \\
(.008)\end{array}$ & $\begin{array}{l}-.054 \\
(.010)\end{array}$ \\
\hline $\begin{array}{l}\text { sinusitis } \\
(\mathrm{obs}=43,493)\end{array}$ & .0652 & $\begin{array}{l}.024 \\
(.004)\end{array}$ & $\begin{array}{l}-.020 \\
(.006)\end{array}$ & $\begin{array}{l}.032 \\
(.008)\end{array}$ & $\begin{array}{l}-.016 \\
(.011)\end{array}$ & $\begin{array}{l}.018 \\
(.005)\end{array}$ & $\begin{array}{l}-.020 \\
(.008)\end{array}$ \\
\hline $\begin{array}{l}\text { heart condition } \\
(\mathrm{obs}=44,499)\end{array}$ & .0203 & $\begin{array}{c}.071 \\
(.009)\end{array}$ & $\begin{array}{l}-.030 \\
(.012)\end{array}$ & $\begin{array}{l}.069 \\
(.013)\end{array}$ & $\begin{array}{l}-.026 \\
(.015)\end{array}$ & $\begin{array}{c}.073 \\
(.014)\end{array}$ & $\begin{array}{l}-.035 \\
(.018)\end{array}$ \\
\hline $\begin{array}{l}\text { diabetes } \\
(\mathrm{obs}=44,197)\end{array}$ & .0016 & $\begin{array}{l}.152 \\
(.042)\end{array}$ & $\begin{array}{l}-.139 \\
(.052)\end{array}$ & $\begin{array}{l}.278 \\
(.136)\end{array}$ & $\begin{array}{l}.203 \\
(.163)\end{array}$ & $\begin{array}{l}.128 \\
(.041)\end{array}$ & $\begin{array}{l}-.174 \\
(.049)\end{array}$ \\
\hline $\begin{array}{l}\text { epilepsy } \\
\text { (obs=44,197) }\end{array}$ & .0043 & $\begin{array}{l}.214 \\
(.032)\end{array}$ & $\begin{array}{l}-.077 \\
(.034)\end{array}$ & $\begin{array}{l}.253 \\
(.051)\end{array}$ & $\begin{array}{l}-.025 \\
(.062)\end{array}$ & $\begin{array}{l}.187 \\
(.038)\end{array}$ & $\begin{array}{l}-.098 \\
(.041)\end{array}$ \\
\hline $\begin{array}{l}\text { freq. headaches } \\
(\mathrm{obs}=44,197)\end{array}$ & .0259 & $\begin{array}{l}.049 \\
(.008)\end{array}$ & $\begin{array}{l}-.037 \\
(.011)\end{array}$ & $\begin{array}{l}.049 \\
(.023)\end{array}$ & $\begin{array}{l}-.142 \\
(.030)\end{array}$ & $\begin{array}{l}.048 \\
(.008)\end{array}$ & $\begin{array}{l}-.035 \\
(.012)\end{array}$ \\
\hline $\begin{array}{l}\text { kidney disease } \\
(\mathrm{obs}=44,197)\end{array}$ & .0031 & $\begin{array}{l}.186 \\
(.035)\end{array}$ & $\begin{array}{l}-.006 \\
(.038)\end{array}$ & $\begin{array}{l}.148 \\
(.051)\end{array}$ & $\begin{array}{l}-.055 \\
(.063)\end{array}$ & $\begin{array}{l}.215 \\
(.048)\end{array}$ & $\begin{array}{l}.030 \\
(.047)\end{array}$ \\
\hline $\begin{array}{l}\text { digestive disorder } \\
(\mathrm{obs}=44,731)\end{array}$ & .0233 & $\begin{array}{l}.076 \\
(.009)\end{array}$ & $\begin{array}{l}-.033 \\
(.010)\end{array}$ & $\begin{array}{l}.068 \\
(.012)\end{array}$ & $\begin{array}{l}-.015 \\
(.011)\end{array}$ & $\begin{array}{l}.085 \\
(.013)\end{array}$ & $\begin{array}{l}-.061 \\
(.018)\end{array}$ \\
\hline $\begin{array}{l}\text { vision problem } \\
(\mathrm{obs}=44,680)\end{array}$ & .0121 & $\begin{array}{l}.056 \\
(.011)\end{array}$ & $\begin{array}{l}-.040 \\
(.015)\end{array}$ & $\begin{array}{l}.109 \\
(.028)\end{array}$ & $\begin{array}{l}-.062 \\
(.036)\end{array}$ & $\begin{array}{c}.038 \\
(.011)\end{array}$ & $\begin{array}{l}-.033 \\
(.106)\end{array}$ \\
\hline $\begin{array}{l}\text { hearing disorder } \\
(\mathrm{obs}=44,680)\end{array}$ & .0174 & $\begin{array}{l}.075 \\
(.011)\end{array}$ & $\begin{array}{l}-.037 \\
(.013)\end{array}$ & $\begin{array}{l}.090 \\
(.018)\end{array}$ & $\begin{array}{l}-.029 \\
(.023)\end{array}$ & $\begin{array}{l}.065 \\
(.013)\end{array}$ & $\begin{array}{l}-.041 \\
(.016)\end{array}$ \\
\hline $\begin{array}{l}\text { mental retardation } \\
(\mathrm{obs}=44,680)\end{array}$ & .0126 & $\begin{array}{l}.107 \\
(.015)\end{array}$ & $\begin{array}{l}-.041 \\
(.017)\end{array}$ & $\begin{array}{l}.171 \\
(.038)\end{array}$ & $\begin{array}{l}-.008 \\
(.036)\end{array}$ & $\begin{array}{l}.085 \\
(.016)\end{array}$ & $\begin{array}{l}-.049 \\
(.019)\end{array}$ \\
\hline $\begin{array}{l}\text { deformity } \\
\text { (obs }=44,680)\end{array}$ & .0350 & $\begin{array}{l}.055 \\
(.007)\end{array}$ & $\begin{array}{l}-.044 \\
(.010)\end{array}$ & $\begin{array}{l}.080 \\
(.015)\end{array}$ & $\begin{array}{l}-.026 \\
(.018)\end{array}$ & $\begin{array}{l}.045 \\
(.007)\end{array}$ & $\begin{array}{l}-.049 \\
(.012)\end{array}$ \\
\hline $\begin{array}{l}\text { has any condition } \\
\text { (obs }=221,600)\end{array}$ & .0702 & $\begin{array}{l}.050 \\
(.002)\end{array}$ & $\begin{array}{l}-.033 \\
(.003)\end{array}$ & $\begin{array}{l}.056 \\
(.003)\end{array}$ & $\begin{array}{l}-.024 \\
(.004)\end{array}$ & $\begin{array}{l}.046 \\
(.003)\end{array}$ & $\begin{array}{l}-.037 \\
(.004)\end{array}$ \\
\hline
\end{tabular}

*Evaluated at median $\ln (\mathrm{y})$.

Note: Robust standard errors in parentheses. Each row contains the results of three identical regressions estimated for different ages groups (0-17, 0-8, and 9-17). For each regression, an indicator of poor health is regressed on the logarithm of family income, denoted as $\ln (\mathrm{y})$, an indicator of whether the child has the health condition listed for that row, and an interaction of $\ln (\mathrm{y})$ and the condition indicator. The effect of the condition on poor health is evaluated at median $\ln (\mathrm{y})$. In addition, each regression includes a complete set of age dummies, year dummies, the logarithm of family size, and indicator variables for whether the child was male, white or black. The coefficient on $\ln (\mathrm{y})$ is not shown in the table, but is negative and significantly different from zero in all regressions. 
Table 4: Bed days and hospitalization episodes per year. 1986-1995 NHIS.

\begin{tabular}{|c|c|c|c|c|}
\hline & \multicolumn{2}{|c|}{ Dep var: annual bed days } & \multicolumn{2}{|c|}{ Dep var: hospitalization episodes. } \\
\hline & $\frac{\text { abed days }}{\text { acondition }}$ & condition $\mathrm{x} \ln (\mathrm{y})$ & $\frac{\text { ahosp.eps }}{\text { acondition }}$ & condition $\mathrm{x} \ln (\mathrm{y})$ \\
\hline hay fever & $\begin{array}{c}1.53 \\
(.232)\end{array}$ & $\begin{array}{l}-.576 \\
(.261)\end{array}$ & $\begin{array}{c}.017 \\
(.006)\end{array}$ & $\begin{array}{l}-.008 \\
(.007)\end{array}$ \\
\hline bronchitis & $\begin{array}{c}4.04 \\
(.289)\end{array}$ & $\begin{array}{l}-1.34 \\
(.379)\end{array}$ & $\begin{array}{l}.067 \\
(.010)\end{array}$ & $\begin{array}{l}-.041 \\
(.013)\end{array}$ \\
\hline asthma & $\begin{array}{c}4.70 \\
(.374)\end{array}$ & $\begin{array}{l}-1.79 \\
(.375)\end{array}$ & $\begin{array}{l}.087 \\
(.011)\end{array}$ & $\begin{array}{l}-.064 \\
(.016)\end{array}$ \\
\hline sinusitis & $\begin{array}{c}2.63 \\
(.291)\end{array}$ & $\begin{array}{l}-.782 \\
(.353)\end{array}$ & $\begin{array}{l}.020 \\
(.007)\end{array}$ & $\begin{array}{l}-.013 \\
(.011)\end{array}$ \\
\hline heart condition & $\begin{array}{c}4.66 \\
(.791)\end{array}$ & $\begin{array}{l}-.588 \\
(.603)\end{array}$ & $\begin{array}{l}.132 \\
(.022)\end{array}$ & $\begin{array}{l}-.006 \\
(.019)\end{array}$ \\
\hline diabetes & $\begin{array}{c}6.87 \\
(3.22)\end{array}$ & $\begin{array}{l}-14.68 \\
(12.20)\end{array}$ & $\begin{array}{l}.247 \\
(.072)\end{array}$ & $\begin{array}{l}.004 \\
(.076)\end{array}$ \\
\hline epilepsy & $\begin{array}{l}17.44 \\
(4.11)\end{array}$ & $\begin{array}{l}-1.20 \\
(4.38)\end{array}$ & $\begin{array}{l}.420 \\
(.070)\end{array}$ & $\begin{array}{l}-.022 \\
(.076)\end{array}$ \\
\hline $\begin{array}{l}\text { frequent } \\
\text { headaches }\end{array}$ & $\begin{array}{c}5.02 \\
(.537)\end{array}$ & $\begin{array}{l}-1.93 \\
(.763)\end{array}$ & $\begin{array}{l}.037 \\
(.009)\end{array}$ & $\begin{array}{l}-.013 \\
(.013)\end{array}$ \\
\hline kidney disease & $\begin{array}{l}14.30 \\
(4.11)\end{array}$ & $\begin{array}{c}2.78 \\
(4.35)\end{array}$ & $\begin{array}{l}.295 \\
(.055)\end{array}$ & $\begin{array}{l}-.107 \\
(.082)\end{array}$ \\
\hline digestive disorder & $\begin{array}{c}3.88 \\
(.447)\end{array}$ & $\begin{array}{l}-2.05 \\
(1.50)\end{array}$ & $\begin{array}{l}.139 \\
(.025)\end{array}$ & $\begin{array}{c}.016 \\
(.012)\end{array}$ \\
\hline vision problem & $\begin{array}{c}3.78 \\
(1.27)\end{array}$ & $\begin{array}{l}-1.12 \\
(1.44)\end{array}$ & $\begin{array}{l}.053 \\
(.018)\end{array}$ & $\begin{array}{l}-.032 \\
(.019)\end{array}$ \\
\hline hearing disorder & $\begin{array}{c}4.35 \\
(.975)\end{array}$ & $\begin{array}{l}-.555 \\
(1.08)\end{array}$ & $\begin{array}{l}.040 \\
(.012)\end{array}$ & $\begin{array}{l}-.028 \\
(.015)\end{array}$ \\
\hline $\begin{array}{l}\text { mental } \\
\text { retardation }\end{array}$ & $\begin{array}{c}4.10 \\
(1.20)\end{array}$ & $\begin{array}{l}.071 \\
(.957)\end{array}$ & $\begin{array}{l}.064 \\
(.018)\end{array}$ & $\begin{array}{l}.022 \\
(.015)\end{array}$ \\
\hline deformity & $\begin{array}{c}4.74 \\
(.696)\end{array}$ & $\begin{array}{l}-.703 \\
(.758)\end{array}$ & $\begin{array}{l}.100 \\
(.013)\end{array}$ & $\begin{array}{l}.143 \\
(.130)\end{array}$ \\
\hline has any condition & $\begin{array}{l}3.601 \\
(.149)\end{array}$ & $\begin{array}{l}-1.25 \\
(.200)\end{array}$ & $\begin{array}{l}.065 \\
(.004)\end{array}$ & $\begin{array}{l}-.023 \\
(.005)\end{array}$ \\
\hline
\end{tabular}

"Evaluated at median $\ln (\mathrm{y})$.

Note: Robust standard errors in parentheses. See notes to Table 2 for the empirical specification and other controls. The marginal effect of the conditions (columns 1 and 3 ) are evaluated at median $\ln$ (family income). 
Table 5: Health status and family income at different ages, PSID Dependent variable: Health status (1=excellent, 5=poor)

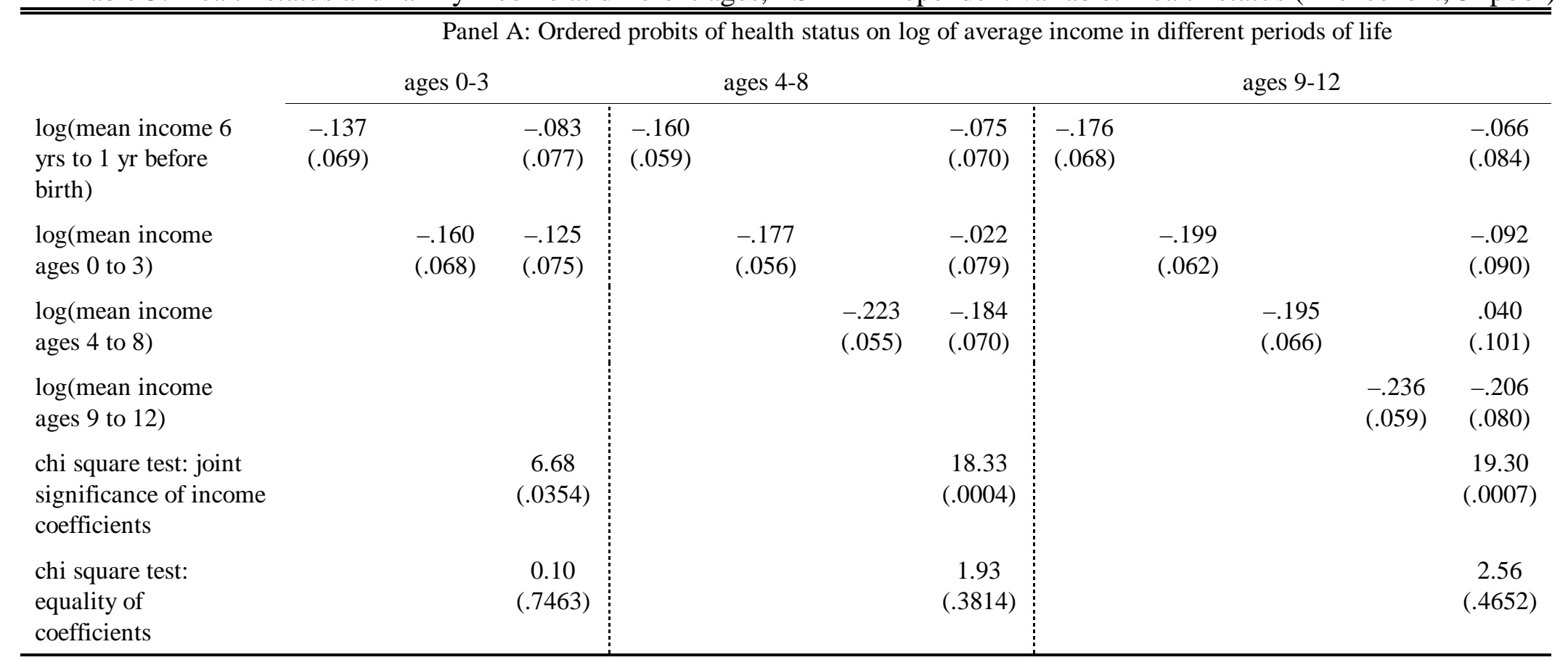

Panel B: Ordered probits of health status on the log of average income during the child's entire life

\begin{tabular}{ll|l|l}
$\log ($ mean income & -.160 & -.253 & -.297 \\
birth year to 1997) & $(.068)$ & $(.063)$ & $(.075)$ \\
\hline
\end{tabular}

Panel C: Ordered probits of health status on the log of average income from 6 years prior to birth through 1997

\begin{tabular}{ll|r:r}
$\log$ (mean income 6 & -.182 & -.257 & -.344 \\
years prior to birth to \\
$1997)$
\end{tabular}

Panel D: Ordered probits of health status on the log of average income from 9 years prior to birth through 1997

\begin{tabular}{|c|c|c|c|c|c|c|c|c|c|c|c|c|}
\hline $\begin{array}{l}\log (\text { mean income } 9 \\
\text { years prior to birth to } \\
\text { 1997) }\end{array}$ & & & $\begin{array}{r}-.183 \\
(.081)\end{array}$ & & & & $\begin{array}{l}-.261 \\
(.072)\end{array}$ & & & & & $\begin{array}{l}-.359 \\
(.088)\end{array}$ \\
\hline Number of obs & 809 & 809 & 809 & 1078 & 1078 & 1078 & 1078 & 883 & 883 & 883 & 883 & 883 \\
\hline
\end{tabular}

Notes: Standard errors in parentheses. All regressions include a complete set of age dummies, and indicators that child is male, white, or black; an indicator that mother is present; mother's age interacted with her presence; mother's education interacted with her presence; an indicator that father is present; father's age interacted with his presence; father's education interacted with his presence; and the log of family size. If a parent's education is missing, the mean education for that sex is assigned, and an indicator variable is included that education is missing. $\log ($ mean income 0 to 3 ) is the $\log$ of the mean income for the household when the child was between the ages of 0 and 3 . Other income variables analogously defined. 
Table 6: Birth health and income, NHIS-CH.

Ordered Probits. Dependent variable is health status (1=Excellent to 5=Poor)

\begin{tabular}{|c|c|c|c|c|c|}
\hline $\ln (y)$ & $\begin{array}{l}-.091 \\
(.020)\end{array}$ & $\begin{array}{l}-.086 \\
(.020)\end{array}$ & $\begin{array}{l}-.082 \\
(.021)\end{array}$ & $\begin{array}{l}-.087 \\
(.020)\end{array}$ & $\begin{array}{l}-.087 \\
(.021)\end{array}$ \\
\hline age & $\begin{array}{l}.067 \\
(.020)\end{array}$ & $\begin{array}{l}.074 \\
(.020)\end{array}$ & $\begin{array}{l}.072 \\
(.020)\end{array}$ & $\begin{array}{l}.065 \\
(.020)\end{array}$ & $\begin{array}{l}.065 \\
(.021)\end{array}$ \\
\hline $\ln (y) x$ age & $\begin{array}{l}-.006 \\
(.002)\end{array}$ & $\begin{array}{l}-.007 \\
(.002)\end{array}$ & $\begin{array}{l}-.007 \\
(.002)\end{array}$ & $\begin{array}{l}-.006 \\
(.002)\end{array}$ & $\begin{array}{l}-.006 \\
(.002)\end{array}$ \\
\hline Indicator: poor birth health & & $\begin{array}{l}.400 \\
(.062)\end{array}$ & $\begin{array}{l}.847 \\
(.315)\end{array}$ & $\begin{array}{l}.397 \\
(.062)\end{array}$ & $\begin{array}{l}.354 \\
(.595)\end{array}$ \\
\hline (Poor birth health) $\mathrm{x}$ age & & $\begin{array}{l}-.026 \\
(.006)\end{array}$ & $\begin{array}{l}-.025 \\
(.006)\end{array}$ & $\begin{array}{l}.029 \\
(.032)\end{array}$ & $\begin{array}{l}.033 \\
(.060)\end{array}$ \\
\hline (Poor birth health) $x \ln (y)$ & & & $\begin{array}{l}-.047 \\
(.032)\end{array}$ & & $\begin{array}{c}.004 \\
(.061)\end{array}$ \\
\hline (Poor birth health) $x \ln (y) x$ age & & & & $\begin{array}{l}-.006 \\
(.003)\end{array}$ & $\begin{array}{l}-.006 \\
(.006)\end{array}$ \\
\hline $\begin{array}{l}\text { Chi-square test: joint sig of birth } \\
\text { health and all birth health interactions. }\end{array}$ & & $\begin{array}{c}48.41 \\
(.0000)\end{array}$ & $\begin{array}{l}50.46 \\
(.0000)\end{array}$ & $\begin{array}{l}51.43 \\
(.0000)\end{array}$ & $\begin{array}{c}51.44 \\
(.0000)\end{array}$ \\
\hline $\begin{array}{l}\text { Chi-square test: joint sig of birth } \\
\text { health interactions }\end{array}$ & & & $\begin{array}{c}20.06 \\
(.0000)\end{array}$ & $\begin{array}{l}20.96 \\
(.0000)\end{array}$ & $\begin{array}{c}20.97 \\
(.0000)\end{array}$ \\
\hline
\end{tabular}

Notes: Standard errors in parentheses. "Poor birth health" is an indicator variable equal to 1 if birth weight is less than $3.5 \mathrm{lbs}$. or the child is in the hospital for one week or longer after the birth. Sample size $=13,841$. Other controls include a complete set of age dummies, the logarithm of family size, indicators variables for whether the child has a mother in the household, a father in the household, whether the child is male, black, or white, interactions of the indicator for whether a mother is in the household with mother's age and mother's education, and interactions of the indicator for whether a father is in the household with father's age and father's education. Other controls include dummy variables for whether both the mother and father were respondents to the health survey, whether the father and not the mother was a respondent to the health survey, and whether neither the mother nor father were respondents to the health survey (the excluded category is that the mother but not the father was the respondent.) 
Table 7: Health status, income, and parental health. NHIS and PSID.

\begin{tabular}{|c|c|c|c|c|c|c|}
\hline \multirow{2}{*}{$\begin{array}{l}\text { NHIS 1986-1995 } \\
\text { ages }\end{array}$} & \multicolumn{6}{|c|}{$\begin{array}{l}\text { Health status ( } 1=\text { excellent, } 5=\text { poor }) \\
\text { Ordered Probits }\end{array}$} \\
\hline & & $0-3$ & $4-8$ & $9-12$ & $13-17$ & \\
\hline obs & & 51,448 & 54,067 & 64,746 & $\begin{array}{l}59,06 \\
9\end{array}$ & \\
\hline $\ln$ (family income) & & $\begin{array}{l}-.048 \\
(.009)\end{array}$ & $\begin{array}{l}-.077 \\
(.008)\end{array}$ & $\begin{array}{l}-.098 \\
(.008)\end{array}$ & $\begin{array}{l}-.125 \\
(.009)\end{array}$ & \\
\hline $\begin{array}{l}\text { mother's health is } \\
\text { excellent or very good }\end{array}$ & & $\begin{array}{l}-.746 \\
(.017)\end{array}$ & $\begin{array}{l}-.782 \\
(.014)\end{array}$ & $\begin{array}{l}-.771 \\
(.013)\end{array}$ & $\begin{array}{l}-.744 \\
(.013)\end{array}$ & \\
\hline $\begin{array}{l}\text { father's health is excellent } \\
\text { or very good }\end{array}$ & & $\begin{array}{l}-.458 \\
(.017)\end{array}$ & $\begin{array}{l}-.489 \\
(.016)\end{array}$ & $\begin{array}{l}-.531 \\
(.015)\end{array}$ & $\begin{array}{l}-.498 \\
(.015)\end{array}$ & \\
\hline PSID & \multicolumn{6}{|c|}{$\begin{array}{l}\text { Health status ( } 1=\text { excellent, } 5=\text { poor }) \\
\text { Ordered Probits }\end{array}$} \\
\hline ages & \multicolumn{2}{|c|}{$0-3$} & \multicolumn{2}{|c|}{$4-8$} & \multicolumn{2}{|c|}{$9-12$} \\
\hline obs & 801 & 801 & 1073 & 1073 & 878 & 878 \\
\hline $\ln ($ current family income) & $\begin{array}{l}-.011 \\
(.052)\end{array}$ & -- & $\begin{array}{l}-.177 \\
(.040)\end{array}$ & -- & $\begin{array}{l}-.109 \\
(.049)\end{array}$ & -- \\
\hline $\begin{array}{l}\ln (\text { mean income } 6 \text { years } \\
\text { prior to birth to current yr) }\end{array}$ & -- & $\begin{array}{l}-.163 \\
(.084)\end{array}$ & -- & $\begin{array}{l}-.249 \\
(.070)\end{array}$ & -- & $\begin{array}{l}-.250 \\
(.086)\end{array}$ \\
\hline $\begin{array}{l}\text { mother's health is } \\
\text { excellent or very good }\end{array}$ & $\begin{array}{l}-.379 \\
(.101)\end{array}$ & $\begin{array}{l}-.374 \\
(.101)\end{array}$ & $\begin{array}{l}-.461 \\
(.084)\end{array}$ & $\begin{array}{l}-.480 \\
(.084)\end{array}$ & $\begin{array}{l}-.496 \\
(.091)\end{array}$ & $\begin{array}{l}-.488 \\
(.091)\end{array}$ \\
\hline $\begin{array}{l}\text { father's health is excellent } \\
\text { or very good }\end{array}$ & $\begin{array}{l}-.202 \\
(.127)\end{array}$ & $\begin{array}{l}-.200 \\
(.127)\end{array}$ & $\begin{array}{l}-.155 \\
(.108)\end{array}$ & $\begin{array}{l}-.136 \\
(.108)\end{array}$ & $\begin{array}{l}-.358 \\
(.116)\end{array}$ & $\begin{array}{l}-.345 \\
(.116)\end{array}$ \\
\hline
\end{tabular}

Notes: Robust standard errors in parentheses. For the NHIS, the sample and set of controls is identical to that used in the lower panel of Table 2, the only different being the addition of the parental health measures. For the PSID, the sample and set of controls is identical to that in Table 5 except for the addition of the parental health measures and the loss of a small number of observations due to missing information on parental health. In all cases, parental health is interacted with an indicator for whether the parent is present in the household. An indicator of whether the parent is present is also included. 
Table 8: Birth parents, other types of parents, and family income. NHIS-CH.

\begin{tabular}{|c|c|c|c|c|}
\hline \multirow[b]{2}{*}{ ages } & \multicolumn{4}{|c|}{$\begin{array}{l}\text { Health status }(1=\text { excellent, } 2=\text { very good, } \\
3=\text { good, } 4=\text { fair, } 5=\text { poor). Ordered probits }\end{array}$} \\
\hline & $0-3$ & $4-8$ & $9-12$ & $13-17$ \\
\hline \multirow[t]{2}{*}{ obs } & 3686 & 3910 & 2842 & 4263 \\
\hline & \multicolumn{2}{|c|}{ Panel A: } & & \\
\hline \multirow[t]{2}{*}{$\ln ($ family income $)$} & $\begin{array}{l}-.104 \\
(.025)\end{array}$ & $\begin{array}{l}-.130 \\
(.025)\end{array}$ & $\begin{array}{l}-.120 \\
(.032)\end{array}$ & $\begin{array}{l}-.202 \\
(.025)\end{array}$ \\
\hline & \multicolumn{2}{|c|}{ Panel B: } & & \\
\hline $\begin{array}{l}\text { (birth mother and birth father)* } \ln (\text { family } \\
\text { income) }\end{array}$ & $\begin{array}{l}-.094 \\
(.034)\end{array}$ & $\begin{array}{l}-.124 \\
(.036)\end{array}$ & $\begin{array}{l}-.104 \\
(.049)\end{array}$ & $\begin{array}{l}-.147 \\
(.041)\end{array}$ \\
\hline $\begin{array}{l}\text { (non-birth mother and non-birth } \\
\text { father)* } \ln \text { (family income) }\end{array}$ & $\begin{array}{l}-.109 \\
(.527)\end{array}$ & $\begin{array}{l}-.155 \\
(.104)\end{array}$ & $\begin{array}{l}-.027 \\
(.111)\end{array}$ & $\begin{array}{l}-.242 \\
(.089)\end{array}$ \\
\hline $\begin{array}{l}\text { Chi-square test: birth mother, birth father = } \\
\text { non-birth mother, non-birth father }\end{array}$ & $\begin{array}{c}0.10 \\
(.752)\end{array}$ & $\begin{array}{c}0.08 \\
(.773)\end{array}$ & $\begin{array}{c}0.44 \\
(.507)\end{array}$ & $\begin{array}{c}0.99 \\
(.320)\end{array}$ \\
\hline
\end{tabular}

Notes: Standard errors in parentheses, except for $C$ hi-square test, which present p-values. All probits include a complete set of age indicators, and indicators that the child is male, white, or black, the log of family size, indicators for whether the mother or father or another adult was the child's health respondent, an indicator that a mother figure is present, and her age and education if present, an indicator that a father figure is present, and his age and education if present. Panel B also includes a complete set of indicators for family type: birth mother and father, birth mother and other father, birth mother only, other mother only, other mother and birth father, birth father only, other father only, or two non-birth parent, and each of these controls interacted with the log of family income. The Chi-square test is for equality of the coefficients for log of family income when child is living with a birth mother and birth father and the $\log$ of family income when the child is living with two non-birth parents. 
Table 9: Health insurance and the effects of chronic conditions on health. NHIS-CH.

\begin{tabular}{|c|c|c|c|c|}
\hline \multicolumn{5}{|c|}{$\begin{array}{l}\text { Ordered Probits. Dependent variable: health } \\
\text { status( } 1=\text { Excellent to } 5=\text { Poor })\end{array}$} \\
\hline $\ln (y)$ & $\begin{array}{l}-.233 \\
(.019)\end{array}$ & $\begin{array}{l}-.223 \\
(.019)\end{array}$ & $\begin{array}{l}-.219 \\
(.019)\end{array}$ & $\begin{array}{l}-.208 \\
(.022)\end{array}$ \\
\hline has condition & $\begin{array}{l}.634 \\
(.231)\end{array}$ & $\begin{array}{l}.649 \\
(.231)\end{array}$ & $\begin{array}{l}.642 \\
(.231)\end{array}$ & $\begin{array}{l}.371 \\
(.274)\end{array}$ \\
\hline $\begin{array}{l}\ln (y) x \text { has } \\
\text { condition }\end{array}$ & $\begin{array}{l}-.024 \\
(.023)\end{array}$ & $\begin{array}{l}-.026 \\
(.023)\end{array}$ & $\begin{array}{l}-.033 \\
(.024)\end{array}$ & $\begin{array}{l}-.005 \\
(.028)\end{array}$ \\
\hline insured & & $\begin{array}{l}-.099 \\
(.032)\end{array}$ & $\begin{array}{l}-.146 \\
(.045)\end{array}$ & $\begin{array}{l}-.167 \\
(.048)\end{array}$ \\
\hline $\begin{array}{l}\text { insured } \mathrm{x} \text { has } \\
\text { condition }\end{array}$ & & & $\begin{array}{c}.090 \\
(.063)\end{array}$ & $\begin{array}{c}.060 \\
(.066)\end{array}$ \\
\hline medicaid & & & & $\begin{array}{l}.093 \\
(.062)\end{array}$ \\
\hline $\begin{array}{l}\text { medicaid } \mathrm{x} \\
\text { has condition }\end{array}$ & & & & $\begin{array}{l}.139 \\
(.083)\end{array}$ \\
\hline $\begin{array}{l}\text { Chi-square tes } \\
\text { insurance vari } \\
\text { jointly insignif }\end{array}$ & & & $\begin{array}{l}11.78 \\
(.0028)\end{array}$ & $\begin{array}{c}17.81 \\
(.0001)\end{array}$ \\
\hline $\begin{array}{l}\text { Chi-square tes } \\
\text { medicaid varia } \\
\text { jointly insignif }\end{array}$ & & & & $\begin{array}{c}17.72 \\
(.0001)\end{array}$ \\
\hline
\end{tabular}

Notes: Robust standard errors in parentheses. Sample size=12,708. "Insured" equals 1 if the child had private insurance of had medicaid coverage. $85.8 \%$ of the children are insured; $12.4 \%$ are on medicaid. "Has condition" equals 1 if the child has had at least of the following types of conditions: vision problem, hearing problem, speech problem, deformity, digestive problem, epilepsy, frequent headaches, heart condition, respiratory problem, tonsilitis, anemia (including sickle cell anemia), a set of infectious diseases (e.g. mononucleosis, hepatitis, pneumonia), a skin or bone condition, frequent ear infections, diabetes or asthma. "Has other condition" is the same as "has condition" except asthma is excluded from the list. All variables in "controls 1" (listed in Table 2) are included in each regression. 
Table 10: Mothers' Labor Force Participation Following the Birth of a Child. PSID.

\begin{tabular}{|c|c|c|c|c|c|c|c|c|c|}
\hline \multirow[b]{2}{*}{$\begin{array}{l}\text { Indicator: low } \\
\text { birth weight or } \\
\text { ICU stay }\end{array}$} & \multicolumn{3}{|c|}{$\begin{array}{l}\text { Indicator: Mother works in } \\
\text { birth year }\end{array}$} & \multicolumn{3}{|c|}{$\begin{array}{c}\text { Indicator: Mother works in } 1^{\text {st }} \\
\text { year after birth }\end{array}$} & \multicolumn{3}{|c|}{$\begin{array}{c}\text { Indicator: Mother works in } 2^{\text {nd }} \\
\text { year after birth }\end{array}$} \\
\hline & $\begin{array}{c}0.015 \\
(0.032)\end{array}$ & $\begin{array}{c}0.009 \\
(0.031)\end{array}$ & $\begin{array}{c}0.014 \\
(0.048)\end{array}$ & $\begin{array}{c}0.023 \\
(0.031)\end{array}$ & $\begin{array}{l}-0.012 \\
(0.031)\end{array}$ & $\begin{array}{l}-0.009 \\
(0.052)\end{array}$ & $\begin{array}{c}0.021 \\
(0.034)\end{array}$ & $\begin{array}{c}0.008 \\
(0.035)\end{array}$ & $\begin{array}{c}0.001 \\
(0.058)\end{array}$ \\
\hline $\begin{array}{l}\text { Indicator: } \\
\text { Mother worked } \\
\text { year before }\end{array}$ & & $\begin{array}{c}0.461 \\
(0.022)\end{array}$ & & & $\begin{array}{c}0.422 \\
(0.023)\end{array}$ & & & $\begin{array}{c}0.384 \\
(0.025)\end{array}$ & \\
\hline $\begin{array}{l}\text { ICU/LBW } \times \\
\text { Mother worked } \\
\text { year before birth }\end{array}$ & & & $\begin{array}{c}0.455 \\
(0.060)\end{array}$ & & & $\begin{array}{c}0.416 \\
(0.061)\end{array}$ & & & $\begin{array}{c}0.394 \\
(0.065)\end{array}$ \\
\hline $\begin{array}{l}\text { Not ICU/LBW } \times \\
\text { Mother worked } \\
\text { year before }\end{array}$ & & & $\begin{array}{c}0.462 \\
(0.024)\end{array}$ & & & $\begin{array}{c}0.423 \\
(0.024)\end{array}$ & & & $\begin{array}{c}0.382 \\
(0.027)\end{array}$ \\
\hline $\begin{array}{l}\text { F-test: } \\
\text { ICU=Not ICU } \\
\text { (p-value) }\end{array}$ & & & $\begin{array}{c}0.01 \\
(.9101)\end{array}$ & & & $\begin{array}{c}0.01 \\
(.9237)\end{array}$ & & & $\begin{array}{c}0.03 \\
(.8696)\end{array}$ \\
\hline \multirow[t]{2}{*}{ Number of obs } & 1996 & 1799 & 1799 & 2083 & 1782 & 1782 & 1722 & 1508 & 1508 \\
\hline & \multicolumn{3}{|c|}{ Mother's hours in birth year } & \multicolumn{3}{|c|}{ Mother's hours $1^{\text {st }}$ year } & \multicolumn{3}{|c|}{ Mother's hours $2^{\text {nd }}$ year } \\
\hline $\begin{array}{l}\text { Indicator: low } \\
\text { birth weight or } \\
\text { ICU stay }\end{array}$ & $\begin{array}{l}68.30 \\
(52.07)\end{array}$ & $\begin{array}{c}32.14 \\
(40.14)\end{array}$ & $\begin{array}{c}46.22 \\
(71.06)\end{array}$ & $\begin{array}{c}86.23 \\
(59.40)\end{array}$ & $\begin{array}{c}23.39 \\
(53.47)\end{array}$ & $\begin{array}{c}17.01 \\
(81.12)\end{array}$ & $\begin{array}{c}20.76 \\
(60.16)\end{array}$ & $\begin{array}{c}9.25 \\
(53.33)\end{array}$ & $\begin{array}{l}-60.71 \\
(78.49)\end{array}$ \\
\hline $\begin{array}{l}\text { Mother's hours } \\
\text { worked in the } \\
\text { year before birth }\end{array}$ & & $\begin{array}{c}0.631 \\
(0.019)\end{array}$ & & & $\begin{array}{l}0.556 \\
(0.021)\end{array}$ & & & $\begin{array}{c}0.524 \\
(0.024)\end{array}$ & \\
\hline $\begin{array}{l}\text { ICU/LBW } \times \\
\text { Mother worked } \\
\text { year before birth }\end{array}$ & & & $\begin{array}{c}0.622 \\
(0.047)\end{array}$ & & & $\begin{array}{c}0.557 \\
(0.056)\end{array}$ & & & $\begin{array}{c}0.571 \\
(0.055)\end{array}$ \\
\hline $\begin{array}{l}\text { Not ICU/LBW } \times \\
\text { Mother worked } \\
\text { year before birth }\end{array}$ & & & $\begin{array}{c}0.633 \\
(0.020)\end{array}$ & & & $\begin{array}{c}0.555 \\
(0.022)\end{array}$ & & & $\begin{array}{c}0.515 \\
(0.026)\end{array}$ \\
\hline $\begin{array}{l}\text { F-test: } \\
\text { ICU/LBW =Not } \\
\text { ICU/LBW } \\
\text { p-value) }\end{array}$ & & & $\begin{array}{c}0.05 \\
(.8271)\end{array}$ & & & $\begin{array}{c}0.00 \\
(.9661)\end{array}$ & & & $\begin{array}{c}0.91 \\
(.3410)\end{array}$ \\
\hline Number of obs & 1996 & 1802 & 1802 & 2083 & 1784 & 1784 & 1723 & 1509 & 1509 \\
\hline
\end{tabular}

Notes: Robust standard errors in parentheses. Also included in all regressions are mother's age and education (if she is present in the household); father's education (if he is present in the household); indicators that mother and father are present in the birth year (columns 1, 4 and 7); in the $1^{\text {st }}$ year after birth (columns 2,5 and 8 ); and in the $2^{\text {nd }}$ year after birth (columns 3, 6 and 9); and indicators that the mother is white and that the mother is black. The variable ICU/LBW is an indicator that the child had a low birth weight (less than 2500 grams, $5.5 \mathrm{lbs}$ ) or that the child was moved to a neo-natal intensive care unit (ICU) after birth. Standard errors are presented in parentheses, and were estimated allowing correlation between unobservables for children in the same household. 
Table 11: Health status and health related behaviors. NHIS-CH. Ordered Probits.

\begin{tabular}{|c|c|c|c|c|}
\hline \multirow[b]{2}{*}{ ages } & \multicolumn{4}{|c|}{$\begin{array}{l}\text { Health status ( } 1=\text { excellent, } 2=\text { very } \\
\text { good, } 3=\text { good, } 4=\text { fair, } 5=\text { poor })\end{array}$} \\
\hline & $0-3$ & $4-8$ & $9-12$ & $13-17$ \\
\hline obs & 3686 & 3910 & 2842 & 4263 \\
\hline $\ln ($ family income) & $\begin{array}{l}-.093 \\
(.026)\end{array}$ & $\begin{array}{l}-.126 \\
(.026)\end{array}$ & $\begin{array}{l}-.114 \\
(.033)\end{array}$ & $\begin{array}{l}-.193 \\
(.025)\end{array}$ \\
\hline $\begin{array}{l}\text { Indicator: }=1 \text { if child has a } \\
\text { regular bedtime }\end{array}$ & $\begin{array}{l}-.048 \\
(.051)\end{array}$ & $\begin{array}{l}-.101 \\
(.054)\end{array}$ & $\begin{array}{l}-.048 \\
(.065)\end{array}$ & $\begin{array}{l}-.133 \\
(.042)\end{array}$ \\
\hline $\begin{array}{l}\text { Indicator: }=1 \text { if someone in } \\
\text { household smokes }\end{array}$ & $\begin{array}{l}.108 \\
(.040)\end{array}$ & $\begin{array}{l}.068 \\
(.039)\end{array}$ & $\begin{array}{l}.063 \\
(.045)\end{array}$ & $\begin{array}{c}.037 \\
(.037)\end{array}$ \\
\hline $\begin{array}{l}\text { Indicator: }=1 \text { if child wears } \\
\text { a seatbelt }\end{array}$ & $\begin{array}{l}-.137 \\
(.059)\end{array}$ & $\begin{array}{l}-.176 \\
(.043)\end{array}$ & $\begin{array}{l}-.117 \\
(.046)\end{array}$ & $\begin{array}{l}-.152 \\
(.038)\end{array}$ \\
\hline $\begin{array}{l}\text { Indicator: }=1 \text { if child has a } \\
\text { place for regular medical } \\
\text { care }\end{array}$ & $\begin{array}{l}-.100 \\
(.093)\end{array}$ & $\begin{array}{l}.023 \\
(.082)\end{array}$ & $\begin{array}{l}.097 \\
(.081)\end{array}$ & $\begin{array}{l}.117 \\
(.065)\end{array}$ \\
\hline $\begin{array}{l}\text { Indicator: }=1 \text { if child has a } \\
\text { place for sick care }\end{array}$ & $\begin{array}{l}.071 \\
(.092)\end{array}$ & $\begin{array}{l}.139 \\
(.094)\end{array}$ & $\begin{array}{l}-.055 \\
(.092)\end{array}$ & $\begin{array}{l}-.078 \\
(.074)\end{array}$ \\
\hline $\begin{array}{l}\text { Indicator: }=1 \text { if routine } \\
\text { doctor's visit in past year }\end{array}$ & $\begin{array}{l}-.049 \\
(.067)\end{array}$ & $\begin{array}{l}.097 \\
(.042)\end{array}$ & $\begin{array}{l}.116 \\
(.045)\end{array}$ & $\begin{array}{l}.094 \\
(.037)\end{array}$ \\
\hline $\begin{array}{l}\text { Chi-square test: joint } \\
\text { significance } \\
\text { (6 health variables) }\end{array}$ & $\begin{array}{l}17.00 \\
(.0093)\end{array}$ & $\begin{array}{c}33.12 \\
(.0000)\end{array}$ & $\begin{array}{l}17.59 \\
(.0074)\end{array}$ & $\begin{array}{c}40.94 \\
(.0000)\end{array}$ \\
\hline
\end{tabular}

Notes: Standard errors in parentheses. See notes to Table 9 for the list of controls included in each ordered probit. 
Table 12: Health conditions and education. NHIS-CH

\begin{tabular}{|c|c|c|c|c|c|}
\hline & \multicolumn{3}{|c|}{ full sample of children aged 5-17 } & $\begin{array}{c}\text { children aged } \\
5-11\end{array}$ & $\begin{array}{c}\text { children aged } \\
12-17\end{array}$ \\
\hline \multicolumn{6}{|c|}{ Dependent Variable $=$ Years of Completed Education } \\
\hline $\ln ($ family income $)$ & $\begin{array}{c}.0764 \\
(.0146)\end{array}$ & $\begin{array}{l}-.1796 \\
(.0397)\end{array}$ & $\begin{array}{l}-.0874 \\
(.0310)\end{array}$ & $\begin{array}{c}.0423 \\
(.0161)\end{array}$ & $\begin{array}{l}.1154 \\
(.025)\end{array}$ \\
\hline has condition & $\begin{array}{l}-.7857 \\
(.2402)\end{array}$ & $\begin{array}{l}-.6904 \\
(.2196)\end{array}$ & $\begin{array}{l}.8136 \\
(.5847)\end{array}$ & $\begin{array}{l}-.3016 \\
(.1945)\end{array}$ & $\begin{array}{r}-1.334 \\
(.461)\end{array}$ \\
\hline $\begin{array}{l}\ln (\text { family income }) \mathrm{x} \\
\text { has condition }\end{array}$ & $\begin{array}{c}.0751 \\
(.0235)\end{array}$ & $\begin{array}{l}.0685 \\
(.0230)\end{array}$ & $\begin{array}{l}-.0820 \\
(.0574)\end{array}$ & $\begin{array}{c}.0276 \\
(.0194)\end{array}$ & $\begin{array}{l}.1280 \\
(.0448)\end{array}$ \\
\hline $\begin{array}{l}\ln (\text { family income }) x \\
\text { age }\end{array}$ & & $\begin{array}{l}.0227 \\
(.0037)\end{array}$ & $\begin{array}{l}.0151 \\
(.0032)\end{array}$ & & \\
\hline has condition $\mathrm{x}$ age & & $\begin{array}{l}-.0026 \\
(.0039)\end{array}$ & $\begin{array}{l}-.1410 \\
(.0673)\end{array}$ & & \\
\hline $\begin{array}{l}\ln (\text { family income }) x \\
\text { age } x \text { has condition }\end{array}$ & & & $\begin{array}{l}.0138 \\
(.0066)\end{array}$ & & \\
\hline observations & 8886 & 8886 & 8886 & 4572 & 4314 \\
\hline
\end{tabular}

Notes: Standard errors in parentheses. Each regression included a complete set of age dummies; indicators for whether a mother and father are present in the home; whether the child is male, white, and black; indicators for the relationship of the child health respondent's) to the child, and the mother's and father's age. "Condition" is defined as in Table 9. 

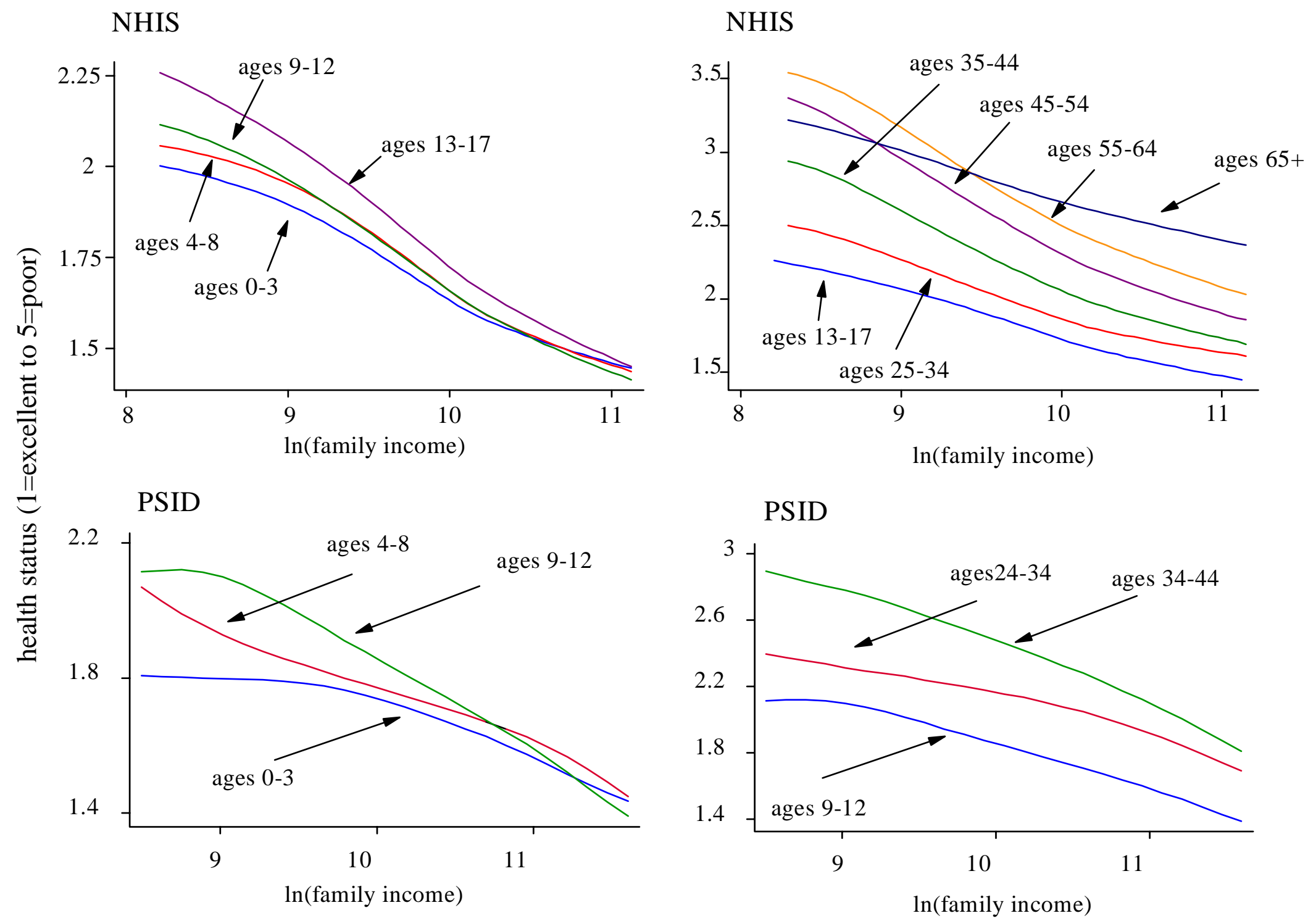

Figure 3.1: Health and income for children and adults. NHIS 1986-1995 and PSID. 

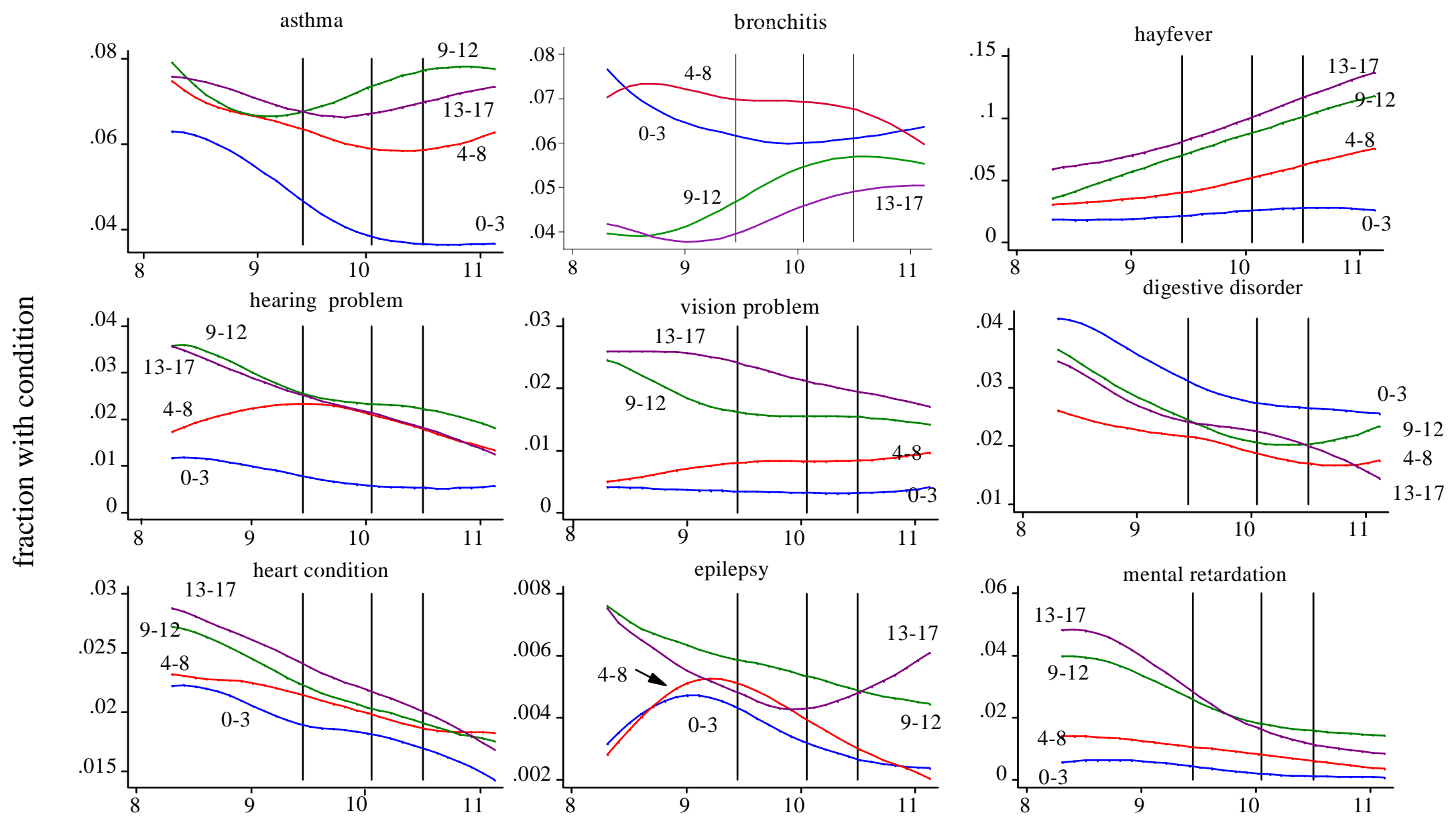

$\ln$ (family income)

Figure 3.2: Gradients in chronic conditions. NHIS 1986-1995. 